\title{
Bacterial diversity and biogeochemistry of different chemosynthetic habitats of the REGAB cold seep (West African margin, $3160 \mathrm{~m}$ water depth)
}

\author{
P. Pop Ristova ${ }^{1,2,3}$, F. Wenzhöfer ${ }^{1,2,3}$, A. Ramette ${ }^{1,2}$, M. Zabel ${ }^{3}$, D. Fischer ${ }^{3}$, S. Kasten , and A. Boetius $^{1,2,3}$ \\ ${ }^{1}$ HGF-MPG Group for Deep Sea Ecology and Technology, Alfred Wegener Institute for Polar and Marine Research, Am \\ Handelshafen 12, 27570 Bremerhaven, Germany \\ ${ }^{2}$ Max Planck Institute for Marine Microbiology, Celsius Strasse 1, 28359 Bremen, Germany \\ ${ }^{3}$ MARUM - Center for Marine Environmental Science, University of Bremen, Leobener Strasse, 28359 Bremen, Germany \\ ${ }^{4}$ Alfred Wegener Institute for Polar and Marine Research, Am Handelshafen 12, 27570 Bremerhaven, Germany \\ Correspondence to: P. Pop Ristova (pristova@marum.de)
}

Received: 11 June 2012 - Published in Biogeosciences Discuss.: 12 July 2012

Revised: 5 November 2012 - Accepted: 15 November 2012 - Published: 7 December 2012

\begin{abstract}
The giant pockmark REGAB (West African margin, $3160 \mathrm{~m}$ water depth) is an active methane-emitting cold seep ecosystem, where the energy derived from microbially mediated oxidation of methane supports high biomass and diversity of chemosynthetic communities. Bare sediments interspersed with heterogeneous chemosynthetic assemblages of mytilid mussels, vesicomyid clams and siboglinid tubeworms form a complex seep ecosystem. To better understand if benthic bacterial communities reflect the patchy distribution of chemosynthetic fauna, all major chemosynthetic habitats at REGAB were investigated using an interdisciplinary approach combining pore water geochemistry, in situ quantification of fluxes and consumption of methane, as well as bacterial community fingerprinting. This study revealed that sediments populated by different fauna assemblages show distinct biogeochemical activities and are associated with distinct sediment bacterial communities. The methane consumption rates and methane effluxes ranged over one to two orders of magnitude across habitats, and reached highest values at the mussel habitat, which hosted a different bacterial community compared to the other habitats. Clam assemblages had a profound impact on the sediment geochemistry, but less so on the bacterial community structure. Moreover, all clam assemblages at REGAB were restricted to sediments characterized by complete methane consumption in the seafloor, and intermediate biogeochemical activity. Overall, variations in the sediment geochemistry were reflected
\end{abstract}

in the distribution of both fauna and microbial communities; and were mostly determined by methane flux.

\section{Introduction}

Cold seeps belong to the most productive ocean ecosystems, and are hence known as oases of life in the deep sea. They are fuelled by energy provided via microbial transformation of methane and higher hydrocarbons, which supports large biomasses of highly specialized chemosynthetic communities (Sibuet and Olu, 1998; Levin, 2005; Jørgensen and Boetius, 2007). Cold seep ecosystems are found on passive and active continental margins around the world's oceans, but represent fragmented, isolated habitats of locally small areal coverage, similar to hydrothermal vents. Ever since the discovery of chemosynthetic communities at cold seep ecosystems (Paull et al., 1984; Kennicutt II et al., 1985; Suess et al., 1985) ecologists have been fascinated by the question of their interconnectivity and biogeography on global and regional spatial scales, just as for hydrothermal vent communities (Tunnicliffe, 1991; Sibuet and Olu, 1998; Tunnicliffe et al., 1998; Tyler et al., 2003; Vanreusel et al., 2009). The most conspicuous characteristics of cold seep ecosystems are seafloor emissions of hydrocarbon fluids and gases as primary, locally restricted energy source causing a specific adaptation of species to their habitat. Furthermore, cold seeps 
show a fragmented distribution along the global continental margins, leading to isolation of populations. Hence, studies dedicated to the geobiology of cold seeps have been seeking to answer the following overarching questions (i) how diverse and specific are microbial and faunal communities at cold seeps compared to the background environment; (ii) to what extent are seep communities indicative of geological processes such as the strength of hydrocarbon seepage; and (iii) which factors control the diversity and dispersal rates of seep-associated organisms on both regional and global scales (among and within cold seeps).

These questions were central to this study of the bacterial communities of the giant pockmark cold seep REGAB (Charlou et al., 2004). Studies investigating seep microorganism have predominantly been focusing on the taxonomical identification of the key microbial players mediating the core energy producing processes, i.e. anaerobic oxidation of methane (AOM) coupled to sulphate reduction (SR) and sulphide oxidation, their phylogenetic affiliation, and relation of their abundances and activities to the local geochemistry (Boetius et al., 2000; Knittel et al., 2003; Heijs et al., 2007; Cambon-Bonavita et al., 2009; Knittel and Boetius, 2010; Orcutt et al., 2010). However, high-resolution studies investigating the structure of microbial communities as a whole, over a range of habitats within a single cold seep ( $\mathrm{m}$ to $\mathrm{km}$ scale) are still rare, hence the abiotic and biotic factors that may directly influence the bacterial diversity at cold seeps remain elusive.

Here we tested the hypotheses that the bacterial diversity at cold seeps changes along geochemical gradients with sediment depth, and moreover that the availabilities of methane and sulphide as main energy sources at cold seeps structure the bacterial communities. Secondly, similar to what has been shown for small-size fauna (Van Gaever et al., 2009), we tested if the type and specific activity of chemosynthetic megafauna can exert a selective pressure and therefore influence bacterial diversity patterns at cold seeps. Therefore we combined pore water geochemistry, quantification of fluxes and consumption rates of methane and bacterial community fingerprinting of the major habitat types at REGAB, populated by different chemosynthetic organisms (mytilid mussels, vesicomyid clams or thiotrophic bacterial mats). The main aims were to better understand (i) if the bacterial community within a cold seep ecosystem varies according to habitat distribution on a "landscape" scale; (ii) if the bacterial diversity is shaped by availability of energy; and (iii) if habitat partitioning by large symbiotic megafauna influences the structure of bacterial communities.

\section{Material and methods}

\subsection{Description of sampling sites and sampling procedure}

The REGAB pockmark, situated at $3160 \mathrm{~m}$ water depth on the Congo-Angola margin represents the second largest ( $800 \mathrm{~m} \varnothing$ and 15-20 m deep) single cold seep site known to date in the Eastern Atlantic (Sibuet and Olu-Le Roy, 2002; Ondréas et al., 2005). REGAB has unusual sedimentological features resulting from the large amount of terrigenous input by the Congo river and the vicinity of one of the largest submarine canyons, the Congo deep-sea fan (Ondréas et al., 2005 and references therein; Pierre and Fouquet, 2007). The pockmark formation has been related to a sudden release of overpressurized gas followed by a collapse of a sediment dome (Ondréas et al., 2005). The current escape of gas is assumed to occur along a deep pipe $(300 \mathrm{~m})$ rooted in a buried paleo-channel (Gay et al., 2003; Ondréas et al., 2005). The seafloor of the REGAB pockmark is characterized by high biomasses of diverse chemosynthetic megafauna which occur clustered as non-overlapping aggregations of mytilid mussels or vesicomyid clams, or siboglinid tubeworms (Ondréas et al., 2005; Olu-Le Roy et al., 2007a).

Video surveys during this study in 2008 (METEOR 76/3b report http://www.dfg-ozean.de/de/berichte/fs_meteor/) revealed that the REGAB pockmark was dominated by the same three major types of megafauna assemblages already discovered during previous investigations of this cold seep in 1998, 2000 and 2001 (Ondréas et al., 2005; Sibuet and Vangriesheim, 2009; Fig. 2). Extensive carbonate cements and outcropping gas hydrates mark the central part of REGAB, where also strong venting of gas and surface precipitates of gas hydrate were observed (Fig. 1). This area was densely populated by mussels and tubeworms attached to the carbonates, and was surrounded by soft sediments littered with clam shells, and patchily distributed beds of living clams. In comparison to the areal coverage of fauna estimated in 2000 (Olu-Le Roy et al., 2007a), the number and sizes of mussel patches associated with soft sediments seemed to have declined with time, as deduced from the Remotely Operated Vehicle (ROV) video observations performed in 2008. However, the spatial distribution of clam species forming heterogeneous patches (Fig. 2) has remained more or less the same, indicating that relatively stable biogeochemical conditions prevail over time at REGAB.

Sediment sampling, in situ geochemical measurement and ROV QUEST (MARUM, Bremen, Germany) video observations at REGAB were performed during the M76/3b cruise in 2008, aboard the R/V Meteor. The eleven investigated sites cluster in three geographical regions of the pockmark (north, south and southwest) and included: 1 bare sediment site where venting of gas bubbles was observed (Gas), 1 bacterial mat (Bacter_N), 3 clam (Clam_N, Clam_S, Clam_SW) and 1 mussel patch (Mussel_S), as well as 6 associated 


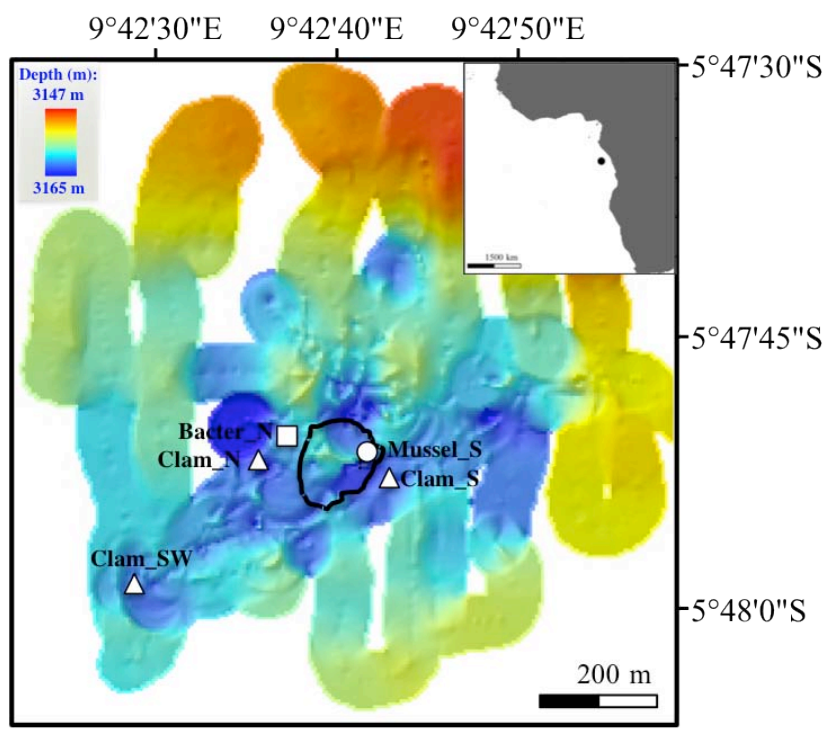

Fig. 1. Map of the REGAB pockmark (adopted from Ondréas et al., 2005), derived from ROV Victor 6000 data (Ifremer, France), with the main sampling locations, i.e. Bacter_N, Clam_N, Mussel_S, Clam_S and Clam_SW. The black line indicates the approximate extension of carbonates with associated mytilids and siboglinids. The investigated bacterial mat is depicted with a square, the various clam patches with triangles and the mussels with a circle symbol.

sites devoid of symbiotic megafauna characterized by bare sediment (Bacter_N_Env, Clam_N_Env, Clam_S_Env, Mussel_S_Env, Clam_SW_Env). Push coring and biogeochemical measurements were not possible in the central carbonatehydrate site, due to the hard substrate at this location. The distances between the megafaunal patches and the adjacent bare sediment were in the range of 3-28 $\mathrm{m}$. Approximate distances between the main sampling locations were: 100 $150 \mathrm{~m}$ between N REGAB and S REGAB, 400-450 $\mathrm{m}$ between S REGAB and SW REGAB and 350-400 m between N REGAB and SW REGAB (Fig. 1). Sampling locations and sample labels are summarized in Table 1 and Supplement Table 1, and all related data are available in the PANGAEA database under doi:10.1594/PANGAEA.788883.

Push core $(\varnothing 8 \mathrm{~cm}$, sediment height $10-20 \mathrm{~cm})$ targeted sampling of the individual habitats was performed using the ROV QUEST camera system and the manipulator arm. Immediately after recovery, the push cores were transferred to a tempered room kept at in situ temperature $\left(4^{\circ} \mathrm{C}\right)$ and subsampled for different type of analyses.

\subsection{Biogeochemical measurements}

\subsubsection{Pore water chemistry}

Pore water was extracted in one centimetre resolution, from the top 0-20 cm sediment depth, using Rhizon moisture samplers (Seeberg-Elverfeldt et al., 2005; pore size $0.1 \mu \mathrm{m}$ ) in-
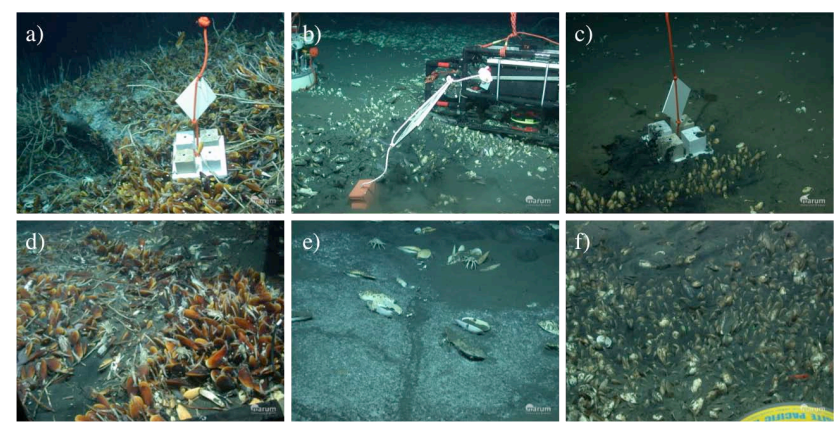

Fig. 2. Typical habitats at the REGAB pockmark: central area with extensive carbonate crust and outcropping hydrates populated by mussels and tubeworms (a); clam patches overlying blackened reduced sediment (b), (c), (f); mussel patch on soft sediment (d); white bacterial mat at the REGAB_N (e); Benthic chamber incubation is visible in (b) picture.

serted into holes of pre-drilled push core liners at all investigated sites (Table 1). The pore water was immediately subsampled for different types of analyses (total $\mathrm{H}_{2} \mathrm{~S}, \mathrm{SO}_{4}^{2-}$, $\mathrm{NH}_{4}^{+}, \mathrm{Fe}^{2+}, \mathrm{Mn}^{2+}, \mathrm{PO}_{4}^{3-}, \mathrm{Cl}^{-}$, and Alkalinity). Description of the measurement procedure for $\mathrm{Fe}^{2+}, \mathrm{Mn}^{2+}, \mathrm{PO}_{4}^{3-}$ as well as $\mathrm{pH}$ can be found in the supplementary material. Alkalinity was calculated from a volumetric analysis by titration of $1 \mathrm{ml}$ of the pore water samples with 0.01 or $0.05 \mathrm{M} \mathrm{HCl}$, performed on board. Concentration of ammonium was determined via the conductivity method (Hall and Aller, 1992) on board. Pore water subsamples $(1.5 \mathrm{~mL})$ were immediately fixed with $0.6 \mathrm{~mL}$ zinc acetate, and the total sulphide $\left(\Sigma \mathrm{H}_{2} \mathrm{~S}=\mathrm{H}_{2} \mathrm{~S}+\mathrm{HS}^{-}+\mathrm{S}^{2-}\right)$ concentration was determined photometrically (Cline, 1969) in the home laboratory. Sulphate and chloride subsamples were diluted 1:100 and stored frozen at $-20^{\circ} \mathrm{C}$ until further processing and determination of the concentration by ion chromatography (Metrohm IC Advanced Compact 861) at a flow rate of $0.7 \mathrm{~mL} \mathrm{~min}^{-1}$.

To estimate the proportions of bio-irrigation and advection on the transport of solutes, the transport-reaction model Explicite was applied (Zabel and Schulz, 2001; Küster-Heins et al., 2010). For this purpose we used the pore water concentration profiles of sulphate and sulphide. Values for sulphate reduction rates used in the model correspond to the analytical results (see Table 2).

\subsubsection{Methane and sulphate consumption rates}

Rates of anaerobic oxidation of methane (AOM) and sulphate reduction (SR) were determined ex situ at all investigated habitats (Table 1). Immediately after recovery, the sediment push cores were subsampled on board in 3 replicates for each of the methods. Following the whole core injection method (Jørgensen, 1978), subcores (Ø $28 \mathrm{~mm}$ ) were injected with either ${ }^{14} \mathrm{CH}_{4}$ or ${ }^{35} \mathrm{SO}_{4}$ radiotracers at $1 \mathrm{~cm}$ 
Table 1. Overview of the sampling sites, their geographic position and type of measurements performed within this study. Sampling and measurements were conducted in July-August 2008. AOM = Anaerobic Oxidation of Methane, SR = Sulphate Reduction, MICP = microprofiler measurement, $\mathrm{CHAM}=$ Benthic Chamber Incubation.

\begin{tabular}{|c|c|c|c|c|}
\hline Location & Sampling site & Latitude & Longitude & Measurement; Sample \\
\hline \multirow{4}{*}{ N REGAB } & $\begin{array}{l}\text { Bacter_N } \\
\text { (Bacterial mat) }\end{array}$ & $5^{\circ} 47.8364^{\prime} \mathrm{S}$ & $9^{\circ} 42.6364^{\prime} \mathrm{E}$ & DNA; Pore water; AOM; SR; MICP \\
\hline & $\begin{array}{l}\text { Bacter_N_Env } \\
\text { (Outside bacterial mat) }\end{array}$ & $5^{\circ} 47.835^{\prime} \mathrm{S}$ & $9^{\circ} 42.6377^{\prime} \mathrm{E}$ & DNA; Pore water; AOM; SR \\
\hline & $\begin{array}{l}\text { Clam_N } \\
\text { (Clam patch) }\end{array}$ & $5^{\circ} 47.836^{\prime} \mathrm{S}$ & $9^{\circ} 42.6164^{\prime} \mathrm{E}$ & DNA; Pore water; AOM; SR; CHAM \\
\hline & $\begin{array}{l}\text { Clam_N_Env } \\
\text { (Outside clam patch) }\end{array}$ & $5^{\circ} 47.842^{\prime} \mathrm{S}$ & $9^{\circ} 42.6304^{\prime} \mathrm{E}$ & DNA; Pore water; AOM; SR; MICP \\
\hline \multirow{4}{*}{ S REGAB } & $\begin{array}{l}\text { Mussel_S } \\
\text { (Mussel patch) }\end{array}$ & $5^{\circ} 47.863^{\prime} \mathrm{S}$ & $9^{\circ} 42.6929^{\prime} \mathrm{E}$ & DNA; Pore water; AOM; SR; CHAM \\
\hline & $\begin{array}{l}\text { Mussel_S_Env } \\
\text { (Outside mussel patch) }\end{array}$ & $5^{\circ} 47.861^{\prime} \mathrm{S}$ & $9^{\circ} 42.685^{\prime} \mathrm{E}$ & DNA; Pore water; AOM; SR; CHAM \\
\hline & $\begin{array}{l}\text { Clam_S } \\
\text { (Clam patch) }\end{array}$ & $5^{\circ} 47.879^{\prime} \mathrm{S}$ & $9^{\circ} 42.6844^{\prime} \mathrm{E}$ & DNA; Pore water; AOM; SR; CHAM \\
\hline & $\begin{array}{l}\text { Clam_S_Env } \\
\text { (Outside clam patch) }\end{array}$ & $5^{\circ} 47.873^{\prime} \mathrm{S}$ & $9^{\circ} 42.684^{\prime} \mathrm{E}$ & DNA; Pore water; AOM; SR; CHAM; MICP \\
\hline REGAB & $\begin{array}{l}\text { Gas } \\
\text { (Gas Bubble) }\end{array}$ & $5^{\circ} 47.865^{\prime} \mathrm{S}$ & $9^{\circ} 42.6954^{\prime} \mathrm{E}$ & DNA; Pore water; AOM; SR \\
\hline \multirow[b]{2}{*}{ SW REGAB } & $\begin{array}{l}\text { Clam_SW } \\
\text { (Clam patch) }\end{array}$ & $5^{\circ} 47.981^{\prime} \mathrm{S}$ & $9^{\circ} 42.4803^{\prime} \mathrm{E}$ & DNA; Pore water; AOM; SR; CHAM \\
\hline & $\begin{array}{l}\text { Clam_SW_Env } \\
\text { (Outside clam patch) }\end{array}$ & $5^{\circ} 47.97^{\prime} \mathrm{S}$ & $9^{\circ} 42.4821^{\prime} \mathrm{E}$ & DNA; Pore water; AOM; SR; CHAM; MICP \\
\hline
\end{tabular}

intervals, according to the procedure described in Felden et al. (2010). Methane and sulphate concentrations were measured by gas chromatography (5890A, Hewlett Packard) and anion exchange chromatography (Waters IC-Pak anion exchange column, waters 430 conductivity detector) in the home laboratory, respectively. Turnover rates of methane and sulphate were determined in the home laboratory by scintillation counting according to Treude et al. (2003) and Kallmeyer et al. (2004), respectively.

\subsubsection{Benthic chamber measurements (TOU and $\mathrm{CH}_{4}$ efflux)}

The Total Oxygen Uptake (TOU) and methane efflux through the sediment-water interface were determined in situ for most of the investigated habitats (Table 1) using an ROV-operated benthic chamber module (CHAM). A technical description of the benthic chamber module (transparent cylinder shape with a diameter of $19 \mathrm{~cm}$ ) and details on the $\mathrm{CH}_{4}$ measurement procedure can be found in Felden et al. (2010) and Duperron et al. (2011). Briefly, $284 \mathrm{~cm}^{2}$ of sediment with $10-15 \mathrm{~cm}$ overlying water (equivalent to a volume of $2.8-$ 4.3 L) was incubated in situ and changes in oxygen and methane concentrations were monitored over time by preprogrammed syringe sampling and optode measurements.
Oxygen concentration in the enclosed bottom water was continuously measured with the help of an oxygen optode, and the TOU flux ( $m$ mol m $\mathrm{m}^{-2} \mathrm{~d}^{-1}$ ) was calculated from the initial linear decrease in $\mathrm{O}_{2}$ concentration versus time (Wenzhöfer and Glud, 2002; Felden et al., 2010). Methane concentrations were determined on water samples taken from the incubated water column, on board using a gas chromatograph (Agilent $6890 \mathrm{~N}$ ) as described previously (Niemann et al., 2009 and references therein). The methane efflux $\left(\mathrm{mmol} \mathrm{m}^{-2} \mathrm{~d}^{-1}\right)$ was calculated as the change of methane concentration in the enclosed bottom water over time (Felden et al., 2010).

\subsubsection{Oxygen microsensor measurements}

A modified version of a deep-sea microprofiler (MICP) was used to carry out high-resolution microsensor measurements $(200 \mu \mathrm{m})$ for in situ determination of oxygen concentrations (Wenzhöfer et al., 2000; Lichtschlag et al., 2010a). Precise positioning and operation of the MICP was achieved with the ROV. Due to the fragile nature of microelectrodes, measurements of the oxygen inventory were restricted only to sites devoid of hard substrates and shell debris, such as the bacterial mat and the bare sediments surrounding the clam patches (Table 1). For each deployment, the MICP carried 3 Clarktype $\mathrm{O}_{2}$ microelectrodes with guard cathode and internal 
reference (Revsbech, 1989). The microsensors were calibrated by applying a two-point calibration (estimated from the $\mathrm{O}_{2}$ concentration in the bottom water and in the anoxic part of the sediment). Bottom water was sampled by means of ROV water sampler (KIPS) (Garbe-Schönberg et al., 2006) and the oxygen concentration was determined with the Winkler titration method (Grasshoff et al., 1999). Diffusive Oxygen Uptake (DOU) was calculated from the linear concentration gradient in the Diffusive Boundary Layer (DBL) by applying Fick's first law of diffusion, as described in (Jørgensen and Des Marais, 1990). The diffusion coefficient of $\mathrm{O}_{2}$ in seawater was corrected for salinity and temperature ( $\mathrm{Li}$ and Gregory, 1974).

\subsection{Bacterial community characterization}

\subsubsection{Bacterial cell numbers}

The total number of single cells was determined at every station by applying the Acridine Orange Direct Count (AODC) method. Push cores were subsampled vertically with smaller cores $(\varnothing 28 \mathrm{~mm})$, which in turn were sliced into $2 \mathrm{~cm}$ sections. Samples were fixed in $4 \%$ formaldehyde/seawater and stored at $4{ }^{\circ} \mathrm{C}$. The AO-staining was done in the home laboratory as previously described (Meyer-Reil, 1983; Boetius and Lochte, 1996). For each sample, a minimum of two replicate filters and 30 grids per filter were randomly counted.

\subsubsection{DNA samples}

On board, sediment cores for DNA analysis were sliced in $2 \mathrm{~cm}$ intervals, down to $18 \mathrm{~cm}$ depth and stored at $-20^{\circ} \mathrm{C}$ for further analysis in the home laboratory. DNA was extracted from one gram of sediment with the Ultra Clean Soil DNA Kit (MoBio Laboratories, Inc., Carlsbad, CA, USA) following the manufacture's recommendations for maximum yields. DNA was finally eluted in $100 \mu \mathrm{L} 1 \times \mathrm{TE}$ buffer (Promega, Madison, WI, USA). DNA quality was confirmed with a gel electrophoresis (1\% agarose gel). Extracted DNA was quantified with a microplate spectrometer (Infinite ${ }^{\circledR} 200$ PRO NanoQuant, TECAN Ltd, Switzerland).

\subsubsection{Automated Ribosomal Intergenic Spacer Analysis (ARISA)}

The bacterial community structure at REGAB was determined by Automated Ribosomal Intergenic Analysis (ARISA; Fisher and Triplett, 1999). Standardized amounts of DNA $(10 \mu \mathrm{L})$ from each sample were amplified in triplicates using the forward FAM-labelled ITSF and reverse ITSReub primers (Cardinale et al., 2004). The PCR procedure, purification of PCR-products, capillary electrophoresis reaction, as well as data transformation were carried out as described previously (Ramette, 2009). The ARISA peaks were binned, using a bin size of $2 \mathrm{bp}$, to account for slight peak shifts between runs and for peak size calling imprecision (In- teractive Binner function, http://www.ecology-research.com; Ramette, 2009).

\subsubsection{Statistical analyses}

All statistical analyses were performed with the open-source software R (The R Project for Statistical Computing v.2.9.2; http://www.r-project.org/) using the "vegan" package (Oksanen et al., 2011). All statistical analyses were restricted to the $0-10 \mathrm{~cm}$ sediment depth. Correlation between differences in geochemical fluxes and $\beta$-diversity, the change in community structure and/or composition among sites calculated using the Bray-Curtis or Jaccard index (Whittaker, 1960), was tested applying the Mantel correlation test based on spearman ranking. The Mantel test is often used in the field of ecology to test the significance of the correlation between two matrices (Ramette, 2007 and references therein), such as in our case the difference in geochemical fluxes and the $\beta$-diversity. The Mantel $\mathrm{p}$-values were corrected for multiple testing using the Bonferroni correction (Ramette, 2007). A reduced data set, including the following sites: Clam $\_$, Clam_S, Clam_S_Env, Mussel_S, Mussel_S_Env, Clam_SW, Clam_SW_Env, and pooled samples within individual habitats $(0-10 \mathrm{~cm}$ merged ARISA peaks) were used for this analysis. All other statistical analyses were performed on individual non-pooled ARISA samples derived from individual sediment depth samples. The bacterial community structure at REGAB was visualized by applying Non-metric MultiDimensional Scaling (NMDS) analysis. The NMDS algorithm ranks distances between objects, and uses these ranks to map the objects nonlinearly onto a simplified, two-dimensional ordination space in order to preserve their ranked differences, and not the original distances (Shepard, 1966). Hence, it has been shown that NMDS is generally efficient at identifying underlying gradients and at representing relationships in various multisample data sets as derived from molecular fingerprinting techniques (Ramette, 2007 and references therein). Separations of groups identified on the NMDS plot were tested for significance using the non-parametric Analysis of Similarity (ANOSIM) test. ANOSIM test compares the ranks of distances (as derived from any distance measure) between two or more groups with the ranks of distances within groups (Clarke, 1993).

Forward selection procedure was used to choose the simplest model that can explain most of the variation in the community. The effect of the geochemistry (pore water concentrations of $\mathrm{CH}_{4}$, total $\mathrm{H}_{2} \mathrm{~S}, \mathrm{SO}_{4}^{2-}, \mathrm{pH}, \mathrm{Mn}^{2+}, \mathrm{Fe}^{2+}, \mathrm{Cl}^{-}$, $\mathrm{PO}_{4}^{3-}$ and alkalinity), space (calculated as geographic distances in $\mathrm{m}$ ), sediment depth and clam presence on the bacterial community structure was assessed by canonical variation partitioning analysis, on a priori Hellinger-transformed response data set (Legendre and Legendre, 1998; Ramette and Tiedje, 2007). This technique (Borcard et al., 1992) aims to partition the total variance of the species (in our case operational taxonomic units - OTUs) table into the 
respective contribution of each set of environmental variables and into their covariations using ordinations (Ramette, 2007 and references therein). The Hellinger-transformation is recommended for data sets that contain many zeros, in order to make them suitable for analyses by linear methods (Legendre and Gallagher, 2001). Single and combined effects of factors in our data set were tested for significance by performing 999 Monte Carlo permutations. Clam presence/absence was dummy-coded assuming that clams directly influence only the topmost $6 \mathrm{~cm}$ of sediment, based on their average shell length and distance reached by their foot.

A distance-based test for homogeneity of multivariate dispersions (Anderson et al., 2006) was applied to test for the influence of the clams on the dispersion of bacterial $\beta$-diversity on smaller scales. The difference among dispersion groups was tested for significance using the Kruskal Wallis and Mann Whitney U test for unmatched samples. The later test was also used to assess if differences in shared OTUs among sites are statistically significant.

As all investigated environmental variables departed from normality, prior to the multivariate analyses, the geochemical data was normalized using the log-transformation, as well as standardized in order to remove the undue influence of magnitude differences between scales or units. Pairwise distances among samples were calculated using the Bray-Curtis dissimilarity index (Bray and Curtis, 1957) for the ARISA diversity data and Euclidean distances for geochemical data (for both, flux and concentration data) prior to the analyses mentioned above.

\section{Results}

\subsection{Visual description of the main habitats at REGAB}

In the northern part of REGAB (REGAB_N; Fig. 2) two main types of habitats were sampled: white thiotrophic bacterial mats (not found in the other parts of REGAB) and clam patches. The two investigated sites (Bacter_N and Clam_N) were found $<36 \mathrm{~m}$ apart. The Clam_N patch was the largest of all investigated patches and was dominated by one clam species - Christineconcha regab (von Cosel and Olu, 2009). The seafloor at REGAB_N was littered with empty and broken shells of clams. Intermingled among the clam shells, high numbers of holothurians could be observed. Additional sampling of the bare sediments surrounding the clam patch (Clam_N_Env) and the bacterial mat (Bacter_N_Env) was also performed.

Two distinct types of megafauna assemblages dominated by either mussels or clams were detected in the southern part of REGAB (REGAB_S; Fig. 2). The different megafauna patches were found close to each other $(20-30 \mathrm{~m})$, however in no occasion did they overlap. Uniquely, at this site (Mussel_S) the mussels were surrounded by soft sediment, thus sampling was possible. Bathymodiolus sp. aff. boomerang
(Olu-Le Roy et al., 2007a) was the mussel patch-forming species. Within the mussel patch, individuals of the siboglinid polychaetes - Escarpia southwardae (Andersen et al., 2004) were visible, as well as numerous shrimps and occasionally galatheid crabs. The investigated clam patch (Clam_S) consisted of Christineconcha regab (von Cosel and Olu, 2009) species buried in dark sediment. No shrimps were observed inhabiting the clams' assemblages. The larger area of the surrounding sediment at the mussel patch was overlain with shell and tubeworm debris compared to the sediment in the vicinity of the clam patch. Two additional sites, located in the vicinity of the respective megafauna assemblages (Clam_S_Env and Mussel_S_Env) were investigated during this study.

Clams were the only chemosynthetic organisms forming assemblages in the southwestern part of REGAB (REGAB_SW; Fig. 2). Distinctly, the sampled patch (Clam_SW) at this part of REGAB was dominated by two species of vesicomyid clams: Christineconcha regab (von Cosel and Olu, 2009) and Laubiericoncha chuni (Thiele and Jaeckel, 1931; von Cosel and Olu, 2009) immersed in very dark sediment. No other vagrant megafauna were noticed to dwell in the Clam_SW clam site upon sampling. The sediment adjacent to the Clam_SW_Env was from one side covered by shell debris, and from the other more or less barren.

\subsection{Biogeochemistry of different habitats at REGAB}

\subsubsection{Pore water geochemistry}

Pore water concentrations of sulphide varied substantially between different habitats of REGAB, both in terms of ranges as well depth profiles (Fig. 3a). The sulphide concentration increased with increasing sediment depth at most of the sampling sites. At the bacterial mat and the mussel habitat $0.1-2 \mathrm{mM}$ of sulphide was detected already in the surface layers. At all investigated clam habitats, as well as the gas bubble site, sulphide was only detected below $3-9 \mathrm{~cm}$ sediment depth (Fig. 3a). The maximum sulphide concentrations at the Mussel_S and Bacter_N sites reached 9 and $11 \mathrm{mM}$, which was almost two times higher (3-6 mM) compared to the maximum concentrations measured at any of the clampopulated sites. Comparison of the sulphide fluxes revealed similar patterns, with highest values measured at the Mussel_S site, followed by slightly lower values at the Bacter_N site (Table 2). The lowest sulphide fluxes $\left(5-9 \mathrm{mmol} \mathrm{m}^{2} \mathrm{~d}^{-1}\right)$ were associated with the clam patches (Clam_N, Clam_S, Clam_SW) (Table 2). The bare sediment sites surrounding the mussel, Clam_N and bacterial patches exhibited even higher ranges of sulphide fluxes, but at the Clam_SW_Env and Clam_S_Env sites no sulphide flux could be detected outside the clam bed (Fig. 3a, Table 2).

Sulphate concentrations decreased with depth at most of the habitats at REGAB due to the anaerobic oxidation of methane, matching well the increasing concentration of 
Table 2. Biogeochemical characterization of different habitats at REGAB. Maximum $\mathrm{H}_{2} \mathrm{~S}$ flux in the sediment, $\mathrm{CH}_{4}$ efflux, total oxygen uptake (TOU), average integrated $(0-10 \mathrm{~cm}$ sediment depth) anaerobic oxidation of methane (AOM) and sulphate reduction (SR) rates, methane consumption efficiency calculated as the percentage of methane consumption (AOM) from the total methane flux $\left(\mathrm{AOM}+\mathrm{CH}_{4}\right.$ efflux), total integrated $(0-10 \mathrm{~cm}$ sediment depth) single cell numbers, as well as alkalinity flux and modelled values of bio-irrigation and advective flow.

\begin{tabular}{|c|c|c|c|c|c|c|c|c|c|c|}
\hline & $\begin{array}{r}\mathrm{H}_{2} \mathrm{~S} \text { flux } \\
(\mathrm{mmol} \\
\left.\mathrm{m}^{-2} \mathrm{~d}^{-1}\right)\end{array}$ & $\begin{array}{r}\mathrm{CH}_{4} \text { efflux } \\
(\mathrm{mmol} \\
\left.\mathrm{m}^{-2} \mathrm{~d}^{-1}\right)\end{array}$ & $\begin{array}{r}\text { TOU } \\
(\mathrm{mmol} \\
\left.\mathrm{m}^{-2} \mathrm{~d}^{-1}\right)\end{array}$ & $\begin{array}{r}\mathrm{AOM} \\
(\mathrm{mmol} \\
\left.\mathrm{m}^{-2} \mathrm{~d}^{-1}\right)\end{array}$ & $\begin{array}{r}\text { Methane } \\
\text { consumption } \\
\text { efficiency } \\
(\%)\end{array}$ & $\begin{array}{r}\mathrm{SR} \\
(\mathrm{mmol} \\
\left.\mathrm{m}^{-2} \mathrm{~d}^{-1}\right)\end{array}$ & $\begin{array}{r}\text { Bio-irrigation } \\
\left(\times 10^{-8}\right) \\
\left(\mathrm{m} \mathrm{s}^{-1}\right)\end{array}$ & $\begin{array}{r}\text { Single cells } \\
\left(\times 10^{10}\right) \\
\left(\mathrm{cm}^{-2}\right. \\
\text { sediment })\end{array}$ & $\begin{array}{r}\text { Alkalinity } \\
\text { flux } \\
(\mathrm{mmol} \\
\left.\mathrm{m}^{-2} \mathrm{~d}^{-1}\right)\end{array}$ & $\begin{array}{r}\text { Advective flow } \\
\left(\times 10^{-8}\right) \\
\left(\mathrm{m} \mathrm{s}^{-1}\right)\end{array}$ \\
\hline Bacter_N & 13 & n.d. & n.d. & 9 & n.d. & 23 & 1 & 0.7 & 0.4 & 0 \\
\hline Bacter_N_Env & 16 & n.d. & n.d. & 9 & n.d. & 3 & 2 & 0.6 & 0.1 & 0 \\
\hline Clam_N & 5 & $<1$ & 50 & 1 & 49 & $<1$ & 4 & 0.7 & 0.1 & 1.4 \\
\hline Clam_N_Env & 9 & n.d. & n.d. & 5 & n.d. & 5 & 4 & 1.5 & 0.3 & 1.0 \\
\hline Clam_S & 6 & 1 & 590 & 6 & 81 & 6 & 5 & 0.9 & 0.1 & 5.0 \\
\hline Clam_S_Env & 0 & 3 & 18 & 3 & 47 & 2 & 2 & 1.0 & 0 & 0 \\
\hline Mussel_S & 20 & $1-81$ & 94 & 19 & 19 & 28 & 2 & 2.7 & 0.4 & 0 \\
\hline Mussel_S_Env & 23 & 334 & 77 & 20 & 6 & 36 & 9 & 3.5 & 0.4 & 6.0 \\
\hline Gas & 7 & n.d. & n.d. & 4 & n.d & 8 & 3 & 1.6 & 0.2 & 0 \\
\hline Clam_SW & 5 & $<1$ & 294 & 3 & 81 & 10 & 5 & 1.4 & 0 & 0 \\
\hline Clam_SW_Env & 0 & 0 & 12 & 2 & 97 & 1 & 1 & 1.0 & 0 & 0 \\
\hline
\end{tabular}

sulphide at the respective sites, as well as the increase in alkalinity (Fig. 3a). At the Bacter_N and Mussel_S sites lowest concentrations of only $2-3 \mathrm{mM}$ were measured at $15-$ $16 \mathrm{~cm}$ sediment depth. In contrast, at all clam-populated sites sulphate penetrated deep into the sediment and substantial amounts (19-24 mM) were measured up to $17 \mathrm{~cm}$ sediment depth. Sulphate was not completely depleted at any of the investigated sites at REGAB (Fig. 3a). Most of the sulphate profiles at the bare sediment sites were similar to the ones measured within the megafauna patches. Exceptions were the Bacter_N_Env and Clam_N_Env sites, where minimum sulphate concentrations of 17 and $10 \mathrm{mM}$ were measured. The sulphate depth profile at the Gas site was similar to the clam patches where sulphate concentrations decreased only after $5 \mathrm{~cm}$ sediment depth. $\mathrm{pH}$ was around 7.6 in the cores, which did not show substantial degassing (see Supplement Fig. 1, also for other pore water constituents not further discussed here).

Ammonium was measured only at few of the investigated sites, due to restricted availability of pore water volumes (Fig. 3b). At both locations (REGAB_S and REGAB_SW), $\mathrm{NH}_{4}^{+}$concentrations were higher inside the clam patches (Clam_S and Clam_SW) relative to the adjacent bare sediment (Clam_S_Env and Clam_SW_Env). Moreover, within the clam patches ammonium was peaking in shallower depths $(3-5 \mathrm{~cm})$, while outside the patches ammonium steadily increased with depth. The ammonium content and depth distribution pattern at the Mussel_S_Env was similar to that of the bare sediment sites in the vicinity of the clam patches.

\subsubsection{Rates of methane and sulphate consumption}

The average integrated $(0-10 \mathrm{~cm})$ sulphate reduction (SR) rates measured at different habitats at REGAB confirmed the trend observed for the sulphide fluxes. The lowest rate of $<1 \mathrm{mmol} \mathrm{m}^{-2} \mathrm{~d}^{-1}$ was observed at Clam_N, and the highest rate of $36 \mathrm{mmol} \mathrm{m}^{-2} \mathrm{~d}^{-1}$ at the Mussel_S_Env (Table 2). Of the habitats populated by different chemosynthetic organisms, the Mussel_S site exhibited highest average integrated SR rates of $28 \mathrm{mmol} \mathrm{m}^{-2} \mathrm{~d}^{-1}$, followed by slightly lower rates at the Bacter_N $\left(23 \mathrm{mmol} \mathrm{m}^{-2} \mathrm{~d}^{-1}\right)$ and lowest integrated SR rates at the clam patches $\left(<1-10 \mathrm{mmol} \mathrm{m}^{-2} \mathrm{~d}^{-1}\right)$. SR rate depth patterns differed substantially among habitats, ranging from surface peaks (Clam_S and Clam_SW) to deep sediment maxima (Bacter_N and Mussel_S_Env) (Supplement Fig. 2). The bare sediment sites had lower SR rates than the adjacent fauna-populated sites, except for the conspicuous Clam_N_Env, where an average integrated SR rate of $4.5 \mathrm{mmol} \mathrm{m}^{-2} \mathrm{~d}^{-1}$ was detected. Sulphate reduction rates at the Bacter_N_Env were an order of magnitude lower compared to the Bacter_N site.

The average integrated $(0-10 \mathrm{~cm})$ rates of anaerobic oxidation of methane (AOM) matched well the corresponding SR rates, and for most of the habitats a $1: 1$ ratio between methane oxidized and sulphate consumed could be observed as predicted by the AOM stoichiometry (Boetius et al., 2000). As already observed when integrated SR rates and sulphide fluxes were compared among fauna-populated habitats, highest integrated AOM average rates were measured at the Mussel_S $\left(19 \mathrm{mmol} \mathrm{m}^{-2} \mathrm{~d}^{-1}\right)$, followed by intermediate rates at the Bacter $\mathrm{N}\left(9 \mathrm{mmol} \mathrm{m}^{-2} \mathrm{~d}^{-1}\right)$ sites and the lowest rates at the clam patches $\left(<1-6 \mathrm{mmol} \mathrm{m}^{-2} \mathrm{~d}^{-1}\right)$ (Clam_N, Clam_S, Clam_SW) (Table 2). Highest peaks of AOM activity were measured in the surface layers $(2.5 \mathrm{~cm})$ at the Bacter $\_\mathrm{N}$ site 
$\left(208 \mathrm{nmol} \mathrm{cm}{ }^{-3} \mathrm{~d}^{-1}\right)$, mid-sediment peaks $(4.5 \mathrm{~cm})$ at the Mussel_S site $\left(465 \mathrm{nmol} \mathrm{cm}^{-3} \mathrm{~d}^{-1}\right)$ and deep-sediment maxima $(8.5 \mathrm{~cm})$ at the Clam_SW site $\left(67 \mathrm{nmol} \mathrm{cm}^{-3} \mathrm{~d}^{-1}\right)$ (Supplement Fig. 2). At the Clam_N site the AOM rates remained low $\left(<11 \mathrm{nmol} \mathrm{cm}{ }^{-3} \mathrm{~d}^{-1}\right)$ throughout the whole investigated sediment depth. The integrated average AOM rates of faunapopulated sites were similar to their adjacent bare sediment sites, despite the difference in the depth-distribution of AOM rates.

\subsubsection{In situ fluxes of methane and oxygen}

$\mathrm{CH}_{4}$ effluxes were hardly detectable with only $<1-$ $3 \mathrm{mmol} \mathrm{m}^{-2} \mathrm{~d}^{-1}$ measured at the investigated clam habitats - both inside and outside the clam patches (Table 2, see also Supplement Fig. 3). The opposite was true for the musselrelated site (Mussel_S_Env), where two orders of magnitude higher methane efflux was measured $\left(334 \mathrm{mmol} \mathrm{m}^{-2} \mathrm{~d}^{-1}\right)$. Within the mussel patch $\mathrm{CH}_{4}$ efflux varied substantially from 1 to $81 \mathrm{mmol} \mathrm{m}^{-2} \mathrm{~d}^{-1}$ (the lower value being measured during the beginning of the incubation and the higher towards the end of the same $3 \mathrm{~h}$ benthic chamber incubation), most probably reflecting temporal variations in the seepage of methane during the period of incubation (Supplement Fig. 3).

The REGAB megafauna contributed substantially to the benthic total oxygen uptake (TOU) measured at all faunapopulated sites (Table 2, see also Supplement Fig. 3). Within the clam patches TOU was on average one order of magnitude higher $\left(50-590 \mathrm{mmol} \mathrm{m}^{-2} \mathrm{~d}^{-1}\right)$ relative to the bare sediment sites $\left(12-18 \mathrm{mmol} \mathrm{m}^{-2} \mathrm{~d}^{-1}\right)$. The TOU measured at the bare sediment site (Mussel_S_Env) adjacent to the mussel patch was approximately four times higher $\left(70 \mathrm{mmol} \mathrm{m}^{-2} \mathrm{~d}^{-1}\right)$ than the other bare sediment sites, and was almost as high as the TOU detected at the Mussel_S site (94 $\mathrm{mmol} \mathrm{m}^{-2} \mathrm{~d}^{-1}$ ).

The Bacter_N site had the highest Diffusive Oxygen Uptake (DOU; $13 \mathrm{mmol} \mathrm{m}^{-2} \mathrm{~d}^{-1}$ ) and shallowest Oxygen Penetration Depth (OPD; $2 \mathrm{~mm}$ ) compared to other investigated sediment sites (Table 3, see also Supplement Fig. 4). The diffusive fluxes of oxygen determined on bare sediments were not uniform, and fluxes changed drastically in dependence on the vicinity of the measurement site to a clam patch. In general, measurements performed on bare sediment found more than $1 \mathrm{~m}$ away from a clam patch, showed deep OPD and low DOU (35-13 mm and $3 \mathrm{mmol} \mathrm{m}^{-2} \mathrm{~d}^{-1}$, respectively), while similar sites located app. $20 \mathrm{~cm}$ from a clam patch exhibited shallower OPD (2-3 mm) and much higher DOU (6$11 \mathrm{mmol} \mathrm{m}^{-2} \mathrm{~d}^{-1}$ ), most probably revealing hotspots of activity in the surrounding of the clam patch.
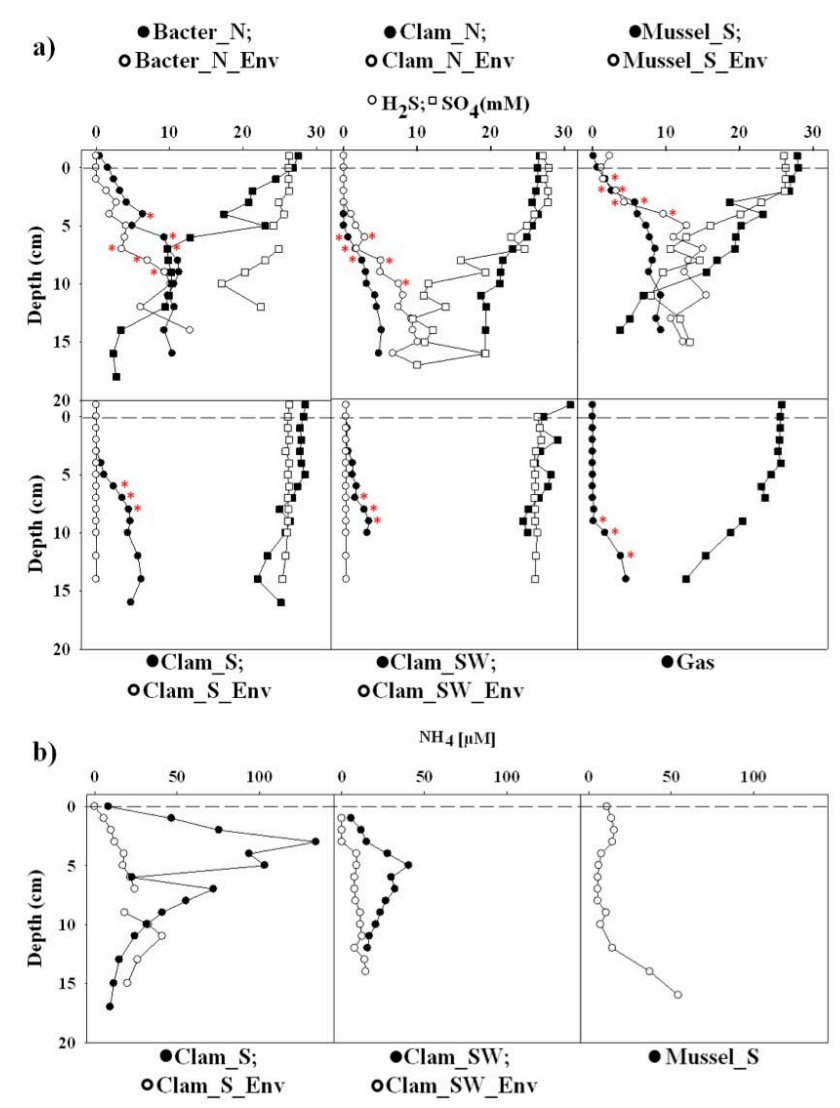

Fig. 3. Geochemical depth profiles of sulphide (circles) and sulphate (squares) (a), as well as ammonium (b) measured at the different habitats at REGAB. Closed symbols denote measurements taken within the patches/bacterial mat, and open symbols denote measurements taken at the nearby bare sediments. Red star symbol $(*)$ denotes the concentration gradients used for calculating the sulphide fluxes presented in Table 2 .

\subsection{Characterization of bacterial communities at REGAB}

\subsubsection{Bacterial cell numbers}

The number of single cells varied substantially among habitats at REGAB. The Mussel_S site had up to two times higher $\left(2.7 \times 10^{10} \mathrm{~cm}^{-2}\right.$ sediment $)$ total integrated $(0-10 \mathrm{~cm})$ cell counts compared to the other fauna-populated sites $\left(0.7-1.4 \times 10^{10} \mathrm{~cm}^{-2}\right.$ sediment) (Table 2). Unusually low cell numbers were detected below the bacterial mat $(0.7 \times$ $10^{10} \mathrm{~cm}^{-2}$ sediment). A sharp decrease in cell numbers with depth was detected at both mussel-related sites (Mussel_S and Mussel_S_Env), while at all other sites the cell numbers remained more or less constant over the entire investigated sediment depth (Supplement Fig. 2). No major differences could be observed among the populated sites and their respective adjacent bare sediment sites, except at REGAB_N area where the Clam_N site had a two times lower 
Table 3. Sediment oxygen penetration depth (OPD) and diffusive oxygen uptake (DOU) of sediments in relation to the vicinity of clam patches and bacterial mat at REGAB, as measured in situ with a microprofiler.

\begin{tabular}{llrr}
\hline & $\begin{array}{l}\text { Distance to clam } \\
\text { patch/bacterial mat }\end{array}$ & $\begin{array}{r}\text { OPD } \\
(\mathrm{mm})\end{array}$ & $\begin{array}{r}\text { DOU }(\mathrm{mmol} \\
\left.\mathrm{m}^{-2} \mathrm{~d}^{-1}\right)\end{array}$ \\
\hline Bacter_N_Env & within bacterial mat & 2 & 13 \\
Clam_S_Env & $<1$ m from clam patch & 2 & 6 \\
Clam_SW_Env & $<1$ m from clam patch & 3 & 11 \\
Clam_N_Env & $>1$ m from clam patch & 35 & 3 \\
Clam_SW_Env & $>1$ m from clam patch & 13 & 3 \\
\hline
\end{tabular}

cell number integrated over depth $\left(0.7 \times 10^{10} \mathrm{~cm}^{-2}\right.$ sediment $)$ compared to the Clam_N_Env site. The Mussel_S_Env was the site with highest cell numbers $\left(3.5 \times 10^{10} \mathrm{~cm}^{-2}\right.$ sediment $)$ at REGAB.

\subsubsection{Bacterial community structure}

The analysis of occurrence, abundance and distribution of bacterial types at the REGAB cold seep was based on defining operational taxonomic units (OTU) representing relatively abundant bacterial populations as detected with the ARISA fingerprinting method (Brown and Fuhrman, 2005; Hewson and Fuhrman, 2006; Böer et al., 2009). Within individual habitats, all horizons sampled from the top $10 \mathrm{~cm}$ sediment depth shared on average only $30 \%$ of the OTUs, with maximum similarity detected at the Gas site $(40 \%)$ and minimum at the Mussel_S (18\%). In general, no depth-related pattern in the OTU richness was observed, except for the mussel sites, Clam_SW and Clam_S_Env which were associated with a decline in the percentage of shared OTUs with increasing depth. Overall 450 unique OTUs were detected across all 11 sites investigated here, with the maximum number of unique OTUs per single site (401) in the top $10 \mathrm{~cm}$ layer at Bacter_N, and the minimum number (252) at Mussel_S_Env. All OTUs occurred at least at 2 sites, and $24 \%$ occurred at all sites. The megafauna and bacterial mat populated sites shared on average $74 \%$ of their OTUs with the adjacent bare sediments (Supplement Table 2). In general the adjacent sites had more OTUs in common compared to more distant sites (Supplement Table 2). The percentage of shared OTUs among samples at the clam-populated sites was not significantly different from the shared OTUs among samples at the non-clam-populated sites (Mann-Whitney U-test for unmatched samples $W=4, p=1$ ) (Supplement Table 3). Finally, no clam habitat-specific bacterial signature was revealed, as shown by the comparison of shared OTUs by all clam patches versus the OTUs present at all other investigated sites at REGAB (Supplement Figs. 5 and 6).

The bacterial community structure of samples from two adjacent sites i.e. samples from within a patch and samples from the respective adjacent bare sediment, grouped very

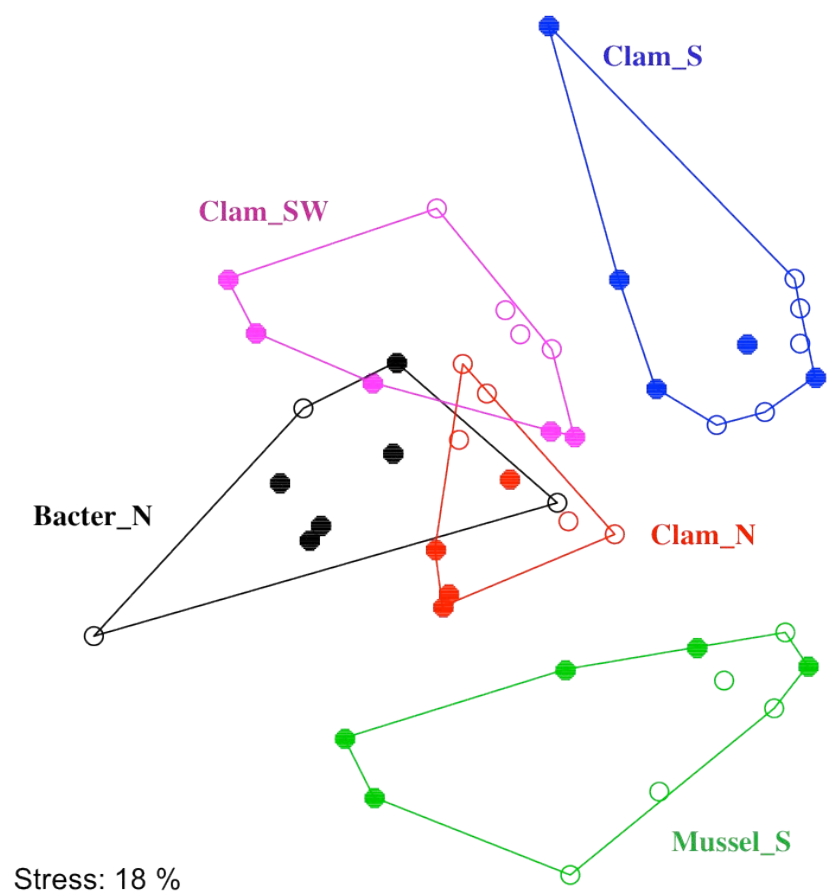

Fig. 4. Non-metric multidimensional scaling (NMDS) ordination plot (based on Bray Curtis distance matrix) of ARISA merged profiles (2-3 PCR replicates were pooled to form a consensus profile). Ordihull grouping of samples $(0-10 \mathrm{~cm})$ according to sampling location (samples from within the patches and the samples from the respective bare sediment were grouped together). NMDS stress $18 \%$. Open symbols denote samples from the bare sediment sites - outside of the respective patch; closed symbols denote samples from within the respective patch.

close to each other, (Fig. 4), indicating high similarities between the patches and the corresponding adjacent bare sediments (here defined as one habitat). Different habitats had different bacterial community structures (Table 4, Fig. 4). The mussel habitat, characterized by highest fluxes and consumption rates of methane and sulphate (Table 2), had a very distinct bacterial community structure, which was significantly different from all other sites (Fig. 4, Table 4). The bacterial mat habitat, where intermediate levels of geochemical fluxes were detected (Table 2) had a rather similar bacterial community with the low-geochemical flux habitats, the Clam_N and Clam_SW habitats (Fig. 4, Table 4). Although all clam habitats had similar low fluxes (Table 2), it was shown that the Clam_S habitat had a significantly different bacterial community structure from the other two clam habitats (Clam_N and Clam_SW) (Table 4, Fig. 4).

Bacterial $\beta$-diversity at REGAB was significantly and positively correlated to differences in $\mathrm{CH}_{4}$ effluxes among sites (Mantel correlation test; Table 5). Marginally significant positive relationships (the relation was not significant when corrected for multiple comparisons, applying the Bonferroni correction) were also revealed between $\beta$-diversity 
Table 4. Analysis of Similarity (ANOSIM; lower triangle), testing for significant differences in bacterial community structure between habitats and percentage of shared OTUs between habitats (upper triangle). ANOSIM R-values (lower triangle) are interpreted as follows: $R<0.25=$ strongly overlapping, $0.25<R<0.5=$ separated but with overlap, $0.5<R<0.75=$ separated with only minor overlap, $R>0.75=$ strongly separated. * $p<0.05$, ** $p<0.01$, *** $<0.001$.

\begin{tabular}{llllll}
\hline & Bacter_N & Clam_N & Mussel_S & Clam_S & Clam_SW \\
\hline Bacter_N & - & 92 & 77 & 80 & 87 \\
Clam_N & 0.3 & - & 78 & 78 & 86 \\
Mussel_S & $0.7^{* *}$ & $0.6^{* *}$ & - & 70 & 76 \\
Clam_S & $0.8^{* * *}$ & $0.8^{* * *}$ & $0.8^{* * *}$ & - & 78 \\
Clam_SW & $0.5^{* *}$ & $0.4^{*}$ & $0.8^{* * *}$ & $0.7^{* *}$ & - \\
\hline
\end{tabular}

and differences in integrated AOM and SR rates, as well as with differences in alkalinity fluxes, but not with variation in any other single pore water parameter (Table 5).

Variation partitioning analysis performed on the full data set, including all pore water concentrations and ARISA samples from all sediment depths, showed that environmental variables comprised under "sediment geochemistry" $(21 \%$, $p=0.001$ ), "space" (geographic distances among sites; $7 \%$, $p=0.001)$, and "sediment depth" (0 to $10 \mathrm{~cm}$, in $1 \mathrm{~cm}$ horizons) ( $2 \%, p=0.012)$ explained most of the variation in the bacterial community structure of REGAB habitats (Fig. 5a). The combined effect of "sediment geochemistry" and "space" accounted for additional $5 \%$ of the observed variations (Fig. 5a). Additional variation partitioning analysis aiming to disentangle the individual effects of the geochemical parameters considered above, revealed that methane sediment concentrations $(5 \%, p=0.001)$ significantly explained the highest portion of the variability in the bacterial community at REGAB, including all sediment depth layers (Fig. 5b). In contrast, sulphide concentrations alone did not significantly account for the variation in the bacterial community, but the confounding effect with the other geochemical parameters explained $6 \%$ of the observed diversity shifts (Fig. 5b). A small portion of the variation in the bacterial community structure at REGAB was related to shifts in alkalinity $(1 \%, p=0.038)$. Finally, the presence of clams had a very small direct overall effect, though not statistically significant, on the bacterial community structure at REGAB ( $1 \%, p=0.106)$ (Fig. 5a). Accordingly, the comparison of the community dispersions among the clampopulated sites and the adjacent bare sediment sites revealed no significant difference (Supplement Table 4).

\section{Discussion}

The giant pockmark REGAB is among the best-studied deepwater cold seeps in terms of biogeographical and geobiological processes shaping faunal communities (Sibuet and Olu-
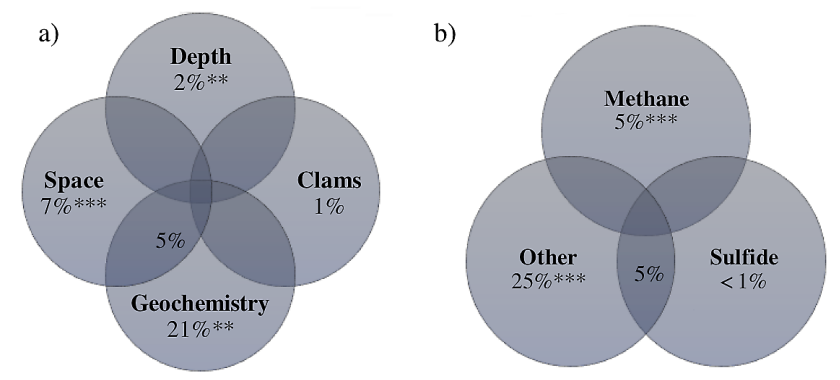

Fig. 5. Variation partitioning analysis. Effect (\%) of the geochemistry (concentrations of $\mathrm{CH}_{4}, \mathrm{H}_{2} \mathrm{~S}, \mathrm{Cl}, \mathrm{Fe}, \mathrm{Mn}, \mathrm{PO}_{4}, \mathrm{SO}_{4}, \mathrm{pH}$ ), clams presence (clams directly influence the top $6 \mathrm{~cm}$ sediment), space (geographic distance among sampling sites) and depth (sediment depth) on the bacterial diversity at REGAB (a). Geochemistry, followed by space and depth, significantly shape the diversity at REGAB. Visualization of the individual influence of $\mathrm{CH}_{4}$ and $\mathrm{H}_{2} \mathrm{~S}$ on the bacterial community structure (b). Other = all parameters included in (a), excluding $\mathrm{CH}_{4}$ and $\mathrm{H}_{2} \mathrm{~S}$ individually. $\mathrm{CH}_{4}$ $(p<0.001)$ significantly explains the variation in the ARISA data set. $* * * p<0.001$, ** $p<0.002, * p<0.03$. The complete model explained $36 \%$ of the total variation in the bacterial diversity at REGAB.

Le Roy, 2002; Olu-Le Roy et al., 2007b; Sibuet and Vangriesheim, 2009; Cordes et al., 2010; Olu et al., 2010). On local scale, previous investigations have matched the distribution of the benthic communities to specific bottom water conditions indicative of methane seepage, and the presence of chemosynthetic megafauna (Olu-Le Roy et al., 2007a; Cambon-Bonavita et al. 2009; Olu et al., 2009; Van Gaever et al., 2009; Menot et al., 2010). This study combines a detailed biogeochemical description of the chemosynthetic megafauna habitats with their bacterial biodiversity, and shows that different biological habitats at REGAB are linked to distinct biogeochemical regimes and specific bacterial communities of the underlying sediment. The main aim was to evaluate the major factors shaping the structure of seep bacterial communities and to gain a better understanding of the complexity and heterogeneity of cold seep ecosystems caused by the interplay of geochemistry, faunal and microbial distribution.

\subsection{Methane flux and its subsurface microbial consumption shapes habitats at the REGAB giant pockmark}

The REGAB pockmark (Menot et al., 2010; this study) comprises highly reduced, patchy habitats where due to the local upward transport of hydrocarbons oxygen, is completely consumed within the first millimetres of seafloor, similar to what was found at other cold seeps (de Beer et al., 2006; Girnth et al., 2010; Lichtschlag et al., 2010a; Grünke et al., 2011). The strongest gas venting in the form of bubble streams and outcropping hydrates were observed at the 
Table 5. Mantel test, checking for correlation between $\beta$-diversity (calculated as Bray-Curtis dissimilarities) and difference in $\mathrm{CH}_{4}$ efflux, Total Oxygen Uptake (TOU), integrated Anaerobic Oxidation of Methane (AOM) and Sulphate Reduction (SR) rate, alkalinity flux, advective flow, integrated sulphide flux and bio-irrigation rate. The spearman rank coefficient was used for calculating correlations. $*=p<0.01$; Bonferroni correction was applied to correct for multiple testing. $(*)$ only significant without Bonferroni correction. Mantel correlation test was performed on pooled ARISA samples $(0-10 \mathrm{~cm}$ depth) according to habitat. For this analysis data from the following sites was used: Clam_N, Mussel_S, Mussel_S_Env, Clam_S, Clam_S_Env, Clam_SW, Clam_SW_Env.

\begin{tabular}{lllllllll}
\hline & $\begin{array}{l}\mathrm{CH}_{4} \\
\text { efflux }\end{array}$ & TOU & AOM & $\begin{array}{l}\text { Bio-irrigation } \\
\text { rate }\end{array}$ & $\begin{array}{l}\text { Alkalinity } \\
\text { flux }\end{array}$ & $\begin{array}{l}\text { Advective } \\
\text { flow }\end{array}$ & $\begin{array}{l}\text { Integrated } \\
\mathrm{H}_{2} \mathrm{~S} \text { flux }\end{array}$ & SR \\
\hline $\begin{array}{l}\text { Mantel } \\
\text { statistics }\end{array}$ & $0.6^{* *}$ & -0.1 & $0.5\left(^{*}\right)$ & 0.2 & $0.5\left(^{*}\right)$ & 0.2 & 0.4 & $0.5\left(^{*}\right)$ \\
$\begin{array}{l}\text { Significance } \\
\text { p-value }\end{array}$ & 0.003 & 0.641 & 0.048 & 0.265 & 0.021 & 0.222 & 0.076 & 0.037 \\
$\begin{array}{l}\text { Bonferroni } \\
\text { corrected } \\
\text { p-value }\end{array}$ & 0.021 & 1 & 0.336 & 1 & 0.147 & 1 & 0.532 & 0.259 \\
\hline
\end{tabular}

central carbonate cements (Fig. 2a). Previous investigations of deep water cold seeps have shown that free gas may escape from the seafloor within the gas hydrate stability zone, even at such high pressure and cold temperature as at REGAB (Suess et al., 1999; Fischer et al., 2012). Methane concentrations in the bottom waters $(10 \mathrm{~cm}$ above seafloor) were highest in the vicinity of the Mussel_S_Env $(3.6 \mu \mathrm{M})$, around $0.4 \mu \mathrm{M}$ at Clam_S_Env to and decreased to $0.2 \mu \mathrm{M}$ at the clam habitat (Clam_SW_Env) furthest away from the central gas vents. These values fall into the low range of values detected previously on top of the respective megafauna patches (Duperron et al., 2005; Olu-Le Roy et al., 2007a).

For the first time we measured in situ methane fluxes from the sedimentary seafloor at REGAB using benthic chambers. Highest methane efflux and also highest methane consumption rates were found at the mussel habitat of REGAB (Mussel_S and Mussel_M_Env). This Bathymodiolus type hosts higher abundance of methane-oxidizing than sulphuroxidizing endosymbionts in the gills, and hence appears to depend mostly on methane as the main source of energy (Duperron et al., 2011). The methane and sulphate consumption rates in the sediments, as well as sulphide fluxes and to a certain extent TOU were 0.5-4 times higher compared to other habitats at REGAB. The high fluxes concomitantly supported up to 2 times higher numbers of bacterial cells at this site relative to the other habitats, and a dense colony of mussels interspersed with tubeworms (Fig. 2b). In a previous study at REGAB, Cambon-Bonavita et al. (2009) detected highest abundances of ANME/SRB aggregates - a microbial consortium shown to mediate AOM coupled to SR processes (Boetius et al., 2000), in the sediments inhabited by mussels. Despite the high AOM rates, the mussel habitat was the only site where extensive seepage of gaseous and dissolved methane was observed, indicating substantial transport of methane to the bottom water. The AOM process removed only $6-20 \%$ of the total upward diffusing methane. Accordingly, the highest bottom water methane concentra- tions were also detected previously above mussel patches at REGAB (Charlou et al., 2004).

Sediments covered by bacterial mats, a common feature of many cold seeps (Treude et al., 2003; Niemann et al., 2006; Lessard-Pilon et al., 2010; Fischer et al., 2012; Grünke et al., 2011), were rather scarce and restricted only to the northern part of REGAB. The sediment below the bacterial mat exhibited intermediate levels of AOM, SR rates and $\mathrm{H}_{2} \mathrm{~S}$ fluxes, approximately 2 times higher than in the clam patches, but lower relative to the mussel patch. At this habitat, SR rates differed by an order of magnitude and SR and AOM rate did not match well, probably reflecting substantial spatial and temporal heterogeneity in the methane transport, as previously observed in relation with bacterial mats and other reduced habitats associated with hydrates (Treude et al., 2003; Lichtschlag et al., 2010b). However, both sites sampled within the bacterial mat habitat were characterized by low single cell counts in comparison to the other habitats at REGAB. In corroboration with our results, CambonBonavita et al. (2009) found that ANME/SRB aggregates were the least abundant in the sediments covered by bacterial mat at the REGAB pockmark, which is a striking contrast to other cold seep settings (Lösekann et al., 2007; Girnth et al., 2010).

The clam patches were the most widely distributed sedimentary chemosynthetic habitats at REGAB. The clam species Christineconcha regab and Laubiericoncha chuni have sulphide-oxidizing symbionts and are not known to use methane directly (von Cosel and Olu, 2009; Krylova and Sahling, 2010). Vast areas within the REGAB pockmark were littered with shells of dead clams, indicating a long-term association and turnover of this bottom-dwelling, mobile chemosynthetic megafauna. The water depth at REGAB is above the calcite compensation depth, hence bivalve shells are not dissolved, and may accumulate over long periods. Independent of their location within REGAB, all clam patches were associated to sediments with similar 
geochemistry. These sediments were characterized by lowest $\mathrm{CH}_{4}$ and $\mathrm{SO}_{4}$ consumption rates, as well as lowest $\mathrm{H}_{2} \mathrm{~S}$ fluxes. Very little to no methane was escaping the sediment at the clam habitats, and AOM accounted for $50-80 \%$ of the upward removal of methane. Lowest bottom water methane concentrations were also detected above clam patches during previous studies at REGAB (Olu-Le Roy et al., 2007a). A common feature of all clam habitats was the absence of sulphide from the topmost surface (up to $5 \mathrm{~cm}$ ) sediment layers. This appears to be a universal characteristics for clam beds at cold seeps, as it has been also shown for other seeps throughout the world i.e. Northern California Seeps (Levin et al., 2003) Cascadia Convergent margin seeps (Sahling et al., 2002), Monterey Bay cold seeps (Barry et al., 1997), Makran accretionary prism (Fischer et al., 2012). The bottom dwelling clams can exploit subsurface sulphide, allowing them to populate cold seeps of low geological activity, where methane and sulphide produced by AOM do not reach surface sediments (Fischer et al., 2012).

The gas bubble site (Gas) was the only other sedimentary site, apart from the mussel habitat, where escape of gas into the water column was observed. Although the AOM and SR rates, as well as sulphide fluxes were in the range of values measured at the clam habitats, the gas bubble site was completely devoid of any visible megafauna. The relatively deep production of sulphide ( $>9 \mathrm{~cm}$ sediment depth) and the low surface methane concentrations can potentially limit the dispersal of megafaunal organisms, which for their survival need more or less constant supply of energy sources i.e. sulphide and/or methane. It is possible that we had sampled a relatively fresh gas vent, which was not yet populated by the slow growing AOM communities transforming methane to sulphide and fuelling other chemosynthetic megafauna.

In this study we could show that the REGAB habitats differ in their methane efflux and pore water geochemistry, and are associated with different types of megafauna. However, methane efflux was relatively similar between the megafauna patches and their direct surroundings. In contrast, oxygen fluxes and oxygen penetration depths were different between the bare sediments and those populated by bacterial mats. Based on the biogeochemical analyses done in our study, the sedimentary habitats at REGAB can be grouped in three categories: (i) mussel-associated sediments, characterized by highest methane efflux, methane consumption and bacterial counts; (ii) bacterial mat-associated sediments, characterized by intermediate activity and low bacterial counts; and (iii) clam-associated sediments, characterized by no methane efflux, intermediate methane consumption and bacterial counts. Overall, the megafauna distribution reflects well the underlying sediment characteristics. The distribution patterns of the seep megafauna reflected methane fluxes and associated biogeochemical characteristics of the underlying seafloor. Thus megafauna assemblages are not only relevant indicators for the presence of seepage (Dando and Hovland, 1992), but also of local seepage activity, i.e. of the magnitude of methane and oxygen fluxes, and of the depth of sulphide production within the sediments.

In general, the magnitude of the measured fluxes and geochemical processes at REGAB fell within the range of values previously reported from other gas hydrate- and carbonatebearing cold seeps (Table 6). A striking exception is the total oxygen uptake, detected within the dense clam patches at REGAB, which to our knowledge represents the highest oxygen consumption ever measured in a cold seep environment (Table 6). The highest flux of dissolved methane at RE$\mathrm{GAB}$, detected at the mussel habitat, was in the range of maximum fluxes reported for bacterial mats at the Hydrate Ridge (Sommer et al., 2006), ampharetid polychaete habitats at the Hikurangi margin (Sommer et al., 2010) and the summit of Dvurechenskii Mud Volcano (DMV; Lichtschlag et al., 2010b; Table 6). AOM and SR rates can vary substantially among different cold seeps, but as well among different habitats within a single cold seep, as it is the case of the REGAB pockmark. The consumption of methane and sulphate at all investigated habitats at REGAB was quite low in comparison to other cold seeps i.e. Hydrate Ridge (Treude et al., 2003), DMV (Lichtschlag et al., 2010b), respectively with ten and five times lower rates relative to maximum reported rates from other cold seeps (Table 6).

\subsection{Methane flux influences bacterial community structure at REGAB}

In addition to investigating the link between methane fluxes and the distribution of chemosynthetic megafauna habitats, we aimed at testing whether (i) the bacterial community structure differs between the different habitats, and (ii) the underlying patterns in bacterial biodiversity are linked to methane fluxes. In this regard, we used several independent measures of seepage activity: the magnitude of methane effluxes, AOM coupled to sulphate consumption rates, sulphide fluxes and alkalinity produced by AOM, and other associated geochemical variables (Table 5; Supplement Figs. 1 and 2). In different ways, these biogeochemical processes are indicative of potential energy availability to the seep communities, with methane and sulphide representing the major sources of reduced chemical energy. Of the different indicators of bacterial diversity analysed here, the bacterial $\beta$ diversity was foremost significantly positively correlated to differences in in situ methane effluxes. A positive trend also existed between the bacterial $\beta$-diversity and the difference in core geochemical processes AOM and SR, as well as alkalinity flux, which usually respond directly to variations in methane supply via AOM or via subsurface fluid advection (Bohrmann et al., 1998; Valentine, 2002; Luff and Wallmann, 2003). These results support the hypothesis (CambonBonavita et al., 2009) that the bacterial community structure at cold seeps is influenced foremost by methane supply, as primary source of energy to anaerobic and aerobic methanotrophs. 
Table 6. Compilation of in situ $\mathrm{CH}_{4}$ effluxes and total oxygen uptake (TOU), ex situ average integrated anaerobic oxidation of methane (AOM) and sulphate reduction (SR) rates, as well as $\mathrm{H}_{2} \mathrm{~S}$ fluxes from cold seep sites worldwide, including data from REGAB (this study).

\begin{tabular}{|c|c|c|c|c|c|c|c|}
\hline Cold seep & Habitat & $\begin{array}{r}\mathrm{CH}_{4} \text { efflux } \\
\left(\mathrm{mmol} \mathrm{m}^{-2} \mathrm{~d}^{-1}\right)\end{array}$ & $\begin{array}{r}\text { AOM } \\
\left(\mathrm{mmol} \mathrm{m}^{-2} \mathrm{~d}^{-1}\right)\end{array}$ & $\begin{array}{r}\text { SR } \\
\left(\mathrm{mmol} \mathrm{m}^{2} \mathrm{~d}^{-1}\right)\end{array}$ & $\begin{array}{r}\mathrm{H}_{2} \mathrm{~S} \text { flux } \\
\left(\mathrm{mmol} \mathrm{m}{ }^{-2} \mathrm{~d}^{-1}\right)\end{array}$ & $\begin{array}{r}\text { TOU } \\
\left(\mathrm{mmol} \mathrm{m}^{-2} \mathrm{~d}^{-1}\right)\end{array}$ & Reference \\
\hline \multirow{3}{*}{$\begin{array}{l}\text { REGAB } \\
\text { (3160 m water depth) }\end{array}$} & Bacterial mat & n.d. & 9 & 23 & 13 & n.d. & \multirow{3}{*}{ This study } \\
\hline & Clam patch & 1 & $3( \pm 2.5)$ & $8( \pm 2.5)$ & $5( \pm 0.6)$ & $311( \pm 294)$ & \\
\hline & Mussel patch & $1-81$ & 19 & 28 & 20 & 94 & \\
\hline $\mathrm{HMMV}^{1}$ (1250 m water depth) & Beggiatoa mat & 78 & $10( \pm 6.6)$ & $14( \pm 6.2)$ & & $101 ; 114$ & Felden et al. (2010) \\
\hline Hydrate Ridge & Beggiatoa mat & $5.7 ; 30 ; 90$ & $5( \pm 4.4) ; 99( \pm 102)$ & $32( \pm 34)$ & $23( \pm 13)$ & 48 & $\begin{array}{l}\text { Treude et al. (2003); } \\
\text { Sahling et al. (2002); } \\
\text { Sommer et al. (2006); } \\
\text { Torres et al. (2002) }\end{array}$ \\
\hline \multirow[t]{2}{*}{ (600-1000 m water depth) } & Clam patch & $0.6 ; 0.45$ & $56( \pm 54)$ & $65( \pm 58)$ & $7( \pm 2.4)$ & 4 & $\begin{array}{l}\text { Treude et al. (2003); } \\
\text { Sahling et al. (2002); } \\
\text { Sommer et al. (2006); } \\
\text { Torres et al. (2002) }\end{array}$ \\
\hline & Acharax field & n.d. & $2( \pm 1.4)$ & $0.4( \pm 0.3)$ & $0.05( \pm 0.05)$ & n.d. & $\begin{array}{l}\text { Treude et al. (2003); } \\
\text { Sahling et al. (2002) }\end{array}$ \\
\hline \multirow{3}{*}{$\begin{array}{l}\mathrm{DMV}^{2}(2060 \text { m water } \\
\text { depth; anoxic Black Sea })\end{array}$} & Summit & 458 & $0.07( \pm 0.1)$ & $0.05( \pm 0)$ & n.d. & 0 & Lichtschlag et al. (2010) \\
\hline & $\begin{array}{l}\text { Geographical } \\
\text { centre of DMV }\end{array}$ & n.d. & $9( \pm 6)$ & $20( \pm 5.7)$ & n.d. & 0 & Lichtschlag et al. (2010) \\
\hline & Western edge & n.d. & $11( \pm 9.6)$ & $108( \pm 38)$ & n.d. & 0 & Lichtschlag et al. (2010) \\
\hline \multirow{2}{*}{$\begin{array}{l}\text { Hikurangi Margin } \\
\text { (1050 m water depth) }\end{array}$} & Ampharetids & $\max .265$ & $17( \pm 9.2)$ & n.d. & n.d. & $\max .118$ & Sommer et al. (2010) \\
\hline & Tube worms & $\max .5$ & n.d. & n.d. & n.d. & $\max .65$ & Sommer et al. (2010) \\
\hline
\end{tabular}

${ }^{1}$ Håkon Mosby Mud Volcano

2 Dvurechenskii Mud Volcano

One may assume that sulphide could biologically influence a higher proportion of bacteria and animals compared to methane. Many types of bacteria can use sulphide as an energy source (Campbell et al., 2006; Sievert et al., 2007), and it is toxic to most animals (Bagarinao, 1992). However, the bacterial $\beta$-diversity was not significantly correlated to difference in sulphide fluxes among habitats. Rather, methane flux was the most important factor structuring the bacterial communities at REGAB. Sulphide is a secondary energy source, provided via microbial methane consumption with sulphate, and it is possible that this indirect link to methane blurs potential relationships with diversity indicators. However, habitat types with similar biogeochemistry/methane fluxes were generally more similar in terms of bacterial diversity as opposed to habitats with distinct geochemistry. The substantial methane flux, as well as the relatively high rates of AOM coupled to SR (Table 2) detected at the mussel patch selected for distinct bacterial communities. In contrast, sites characterized by low to intermediate rates of AOM coupled to SR and hardly detectable methane fluxes, such as those measured at the clam patches and the bacterial mat, had highly similar bacterial community structure. Similarly, previous studies have shown that the composition, distribution and densities of mega-, macro- and meiofauna at REGAB (Olu-Le Roy et al., 2007a; Olu et al., 2009; Van Gaever et al., 2009; Menot et al., 2010), as well as at other seeps (Sahling et al., 2008; Levin et al., 2010; Decker et al., 2011; Ritt et al., 2011; Fischer et al., 2012), are (in)directly linked to variations in the methane content, along with the oxygen inventory and the type of seafloor substrate.
A further analysis of the links between community structure and concentrations of pore water constituents across all individual depth samples also confirmed a link between $\beta$ diversity and sediment geochemistry (Fig. 5). Even when using ex situ methane concentrations in the analysis (i.e. after degassing and depressurization of the cores upon retrieval), pore water methane concentrations explained the highest proportion of the variation in the bacterial community structure. Again, sulphide concentrations could not explain any variation in the bacterial community structure, however, the confounding effect of this variable with the rest of the geochemical parameters accounted for a substantial portion of the variation in the community structure at REGAB, as did sediment depth and geographic distance between samples (Fig. 5). Geographic (spatial) distance among sampling sites and to lesser extent sediment depth of individual samples are two other variables that appeared to play a role in shaping the bacterial communities at REGAB. Of course, both are also coupled strongly to geological and geochemical processes, e.g. distance to gas seepage, or upward transport of highly reduced pore water fluids to the sulphate or oxygen penetrated sediment surface layer, and their role in structuring bacterial diversity cannot be further disentangled in this study.

Although only a small proportion of the total bacterial community can use methane directly as energy source, we propose that methane oxidation, as the primary energy producing process in the seep ecosystem, is a main driver of community structure, from bacteria to megafauna. Previous studies of $\beta$-diversity patterns of benthic bacterial communities have shown significant relationships to geobiological indicators of energy availability, such as phytodetritus 
sedimentation to oligotrophic continental margins (Bienhold et al., 2012), and benthic primary productivity in coastal sands (Böer et al., 2009).

\subsection{Link between megafauna, geochemistry and bacterial community structure}

A further aim of this study was to test whether the occurrence of the chemosynthetic megafauna, influences bacterial community structure and the local geochemistry of the underlying sediments. It has previously been shown that chemosynthetic megafauna alters its local environment by bioturbation, bio-irrigation, burrowing and by exudates (Barry et al., 1997; Levin et al., 2003; Fischer et al., 2012). Clam respiration accounted for a substantial local increase (25-30 times) in the total benthic oxygen uptake rates, as compared to the adjacent bare sediments (Table 2). At both Clam_S and Clam_SW sites roughly $96-97 \%$ (calculated as the percentage of difference in total oxygen uptake (TOU) between the clam populated and bare sediment sites) of the total oxygen uptake was due to clam respiration. Difference in the TOU measured among the clam sites $\left(590 \mathrm{mmol} \mathrm{m}^{-2} \mathrm{~d}^{-1}\right.$ at the Clam_S and $294 \mathrm{mmol} \mathrm{m}^{-2} \mathrm{~d}^{-1}$ at the Clam_SW) can most probably be explained by the difference in clam density within the assemblages, rather than by variations in the individual respiration rates (Decker et al., 2012). In contrast, mussels contributed only $18 \%$ to the total oxygen uptake. In contrast to the clams, the Bathymodiolus mussels contain a high proportion of methanotrophic symbionts (Duperron et al., 2009, 2011; Petersen and Dubilier, 2009), causing a reduction of methane efflux within the mussel patch. If we assume that the difference in the methane effluxes between Mussel_S $\left(81 \mathrm{mmol} \mathrm{m}^{-2} \mathrm{~d}^{-1}\right)$ and Mussel_S_Env $\left(334 \mathrm{mmol} \mathrm{m}^{-2} \mathrm{~d}^{-1}\right)$ is due to the uptake by the mussels, they would consume approximately 12 times more methane $\left(253 \mathrm{mmol} \mathrm{m}^{-2} \mathrm{~d}^{-1}\right)$ than what is consumed via the process of anaerobic oxidation (AOM; $20 \mathrm{mmol} \mathrm{m}^{-2} \mathrm{~d}^{-1}$ ) (see Table 2).

Similar to clam habitats at other cold seeps, sulphide was absent from the surface sediments at REGAB (Barry et al., 1997; Sahling et al., 2002; Levin et al., 2003; Fischer et al., 2012). Bottom water sulphate penetrated till $6 \mathrm{~cm}$ depth at all clam patches at REGAB. Such geochemical signature is usually ascribed to the dwelling activity of thiotrophic clams to access sulphide (Childress and Fisher, 1992), leading to a deeper sulphate penetration (Sahling et al., 2002; Cordes et al., 2005, 2010; Fischer et al., 2012). Furthermore, unusual and elevated ammonium concentrations were measured below the clam patches, where the maximum concentrations - indicating local production of ammonium, were observed within the depth range of the clam foot. Previous studies from the Gulf of Mexico cold seeps also showed that clamassociated sediments had very high ammonium concentrations (Joye et al., 2010). These results indicate a potential link between the clam presence and the $\mathrm{NH}_{4}^{+}$concentrations in pore water, most probably via local excretions of metabo- lites by the clams, but further investigations are needed to decipher this relation. However, when comparing the structure of bacterial communities of adjacent sites at REGAB with and without chemosynthetic megafauna or bacterial mats, both methane fluxes and bacterial community structure were similar (Fig. 4, Table 2). Accordingly, no direct association of unique bacterial types with the different megafauna was detected. Even the dense clam patches had little effect on the bacterial community structure. This indicates that the abundant bacterial types in this cold seep ecosystem as detected by ARISA fingerprinting were directly affected by methane seepage and other geochemical processes, but only indirectly by the presence and absence of megafauna types. This finding may differ with high-resolution sampling targeting, e.g. the surface of bivalves and their burrows, and with other types of molecular methods, which detect rare bacterial types. Furthermore, space played an important role in structuring the distribution and diversity of chemosynthetic megafauna and bacterial communities at spatial scales of meters to hundreds of meters, which needs further investigation, especially when considering the need for conservation, protection and management of cold seeps as unique deep-water ecosystems.

\section{Supplementary material related to this article is available online at: http://www.biogeosciences.net/9/ 5031/2012/bg-9-5031-2012-supplement.pdf.}

Acknowledgements. We thank the captain and crew of $\mathrm{R} / \mathrm{V}$ Meteor expedition M76/2 GUINECO and the pilots of ROV Quest (MARUM) for their invaluable help with work at sea. Christina Bienhold, Rafael Stiens, Tomas Wilkop and Oluwatobi Oni are gratefully acknowledged for the sediment sampling onboard and André Gaßner, Jens Gröger, Jörn Tonnius and Christan Le Gall for help with pore water and methane analyses. We thank Volker Asendorf for his support with the in situ instruments. We are grateful to Gabi Schüssler and Anne-Kathrin Saul for the help with biogeochemical rate and AODC measurements, respectively. We thank Karine Olu for discussions of the sampling strategy, Helene Ondréas for providing the REGAB map, and Stefanie Grünke for help with processing. We further thank two anonymous reviewers for helping to improve this manuscript. This study was funded by the DFG (METEOR expedition), the Research Center/Cluster of Excellence "The Ocean in the Earth System" (MARUM) Project GB5 at the University Bremen) and the Max Planck Institute for Marine Microbiology, Bremen, Germany.

The service charges for this open access publication have been covered by the Max Planck Society.

Edited by: K. Küsel 


\section{References}

Anderson, M. J., Ellingsen, K. E., and McArdle, B. H.: Multivariate dispersion as a measure of beta diversity., Ecol. Lett., 9, 683-693, doi:10.1111/j.1461-0248.2006.00926.x, 2006.

Bagarinao, T.: Sulfide as an environmental factor and toxicant: tolerance and adaptations in aquatic organisms, Aquat. Toxicol., 24, 21-62, 1992.

Barry, J. P., Kochevar, R. E., and Baxter, C. H.: The influence of pore-water chemistry and physiology on the distribution of vesicomyid clams at cold seeps in Monterey for patterns of Bay: Implications chemosynthetic community organization, Limnol. Oceanogr., 42, 318-328, 1997.

Bienhold, C., Boetius, A., and Ramette, A.: The energy-diversity relationship of complex bacterial communities in Arctic deepsea sediments, ISME J., 6, 724-732 doi:10.1038/ismej.2011.140, 2012.

Boetius, A. and Lochte, K.: Effect of organic enrichments on hydrolytic potentials and growth of bacteria in deep-sea sediments, Mar. Ecol.-Prog. Ser., 140, 239-250, 1996.

Boetius, A., Ravenschlag, K., Schubert, C. J., Rickert, D., Widdel, F., Gieseke, A., Amann, R., Jørgensen, B. B., Witte, U., and Pfannkuche, O.: A marine microbial consortium apparently mediating anaerobic oxidation of methane, Nature, 407, 623-626, doi:10.1038/35036572, 2000.

Bohrmann, G., Greinert, J., Erwin, S., and Torres, M.: Authigenic carbonates from Cascadia Subduction Zone and their relation to gas hydrate stability, Geology, 26, 647-650, 1998.

Borcard, D., Legendre, P., and Drapeau, P.: Partialling out the spatial component of ecological variation, Ecol. Soc. Am., 73, 10451055, 1992.

Bray, R. J. and Curtis, J. T.: An ordination of upland forest communities of southern Wisconsin, Ecol. Monogr., 27, 325-349, 1957.

Brown, M. V. and Fuhrman, J. A.: Marine bacterial microdiversity as revealed by internal transcribed spacer analysis, Aquat. Microb. Ecol., 41, 15-23, doi:10.3354/ame041015, 2005.

Böer, S. I., Hedtkamp, S. I. C., Beusekom, J. E. E. V., Fuhrman, J. A., Boetius, A., and Ramette, A.: Time- and sediment depth-related variations in bacterial diversity and community structure in subtidal sands, ISME J., 3, 780-791, doi:10.1038/ismej.2009.29, 2009.

Cambon-Bonavita, M. A., Nadalig, T., Roussel, E., Delage, E., Duperron, S., Caprais, J. C., Boetius, A., and Sibuet, M.: Diversity and distribution of methane-oxidizing microbial communities associated with different faunal assemblages in a giant pockmark of the Gabon continental margin, Deep-Sea Res. Pt. II, 56, 2248-2258, doi:10.1016/j.dsr2.2009.04.007, 2009.

Campbell, B. J., Engel, A. S., Porter, M. L., and Takai, K.: The versatile epsilon-proteobacteria: key players in sulphidic habitats., Nature Rev. Microbiol., 4, 458-468, doi:10.1038/nrmicro1414, 2006.

Cardinale, M., Brusetti, L., Quatrini, P., Borin, S., Puglia, A. M., Rizzi, A., Zanardini, E., Sorlini, C., Corselli, C., and Daffonchio, D.: Comparison of Different Primer Sets for Use in Automated Ribosomal Intergenic Spacer Analysis of Complex Bacterial Communities, Appl. Environ. Microb., 70, 6147-6156, doi:10.1128/AEM.70.10.6147-6156.2004, 2004.

Charlou, J. L., Donval, J. P., Fouquet, Y., Ondreas, H., Knoery, J., Cochonat, P., Levaché, D., Poirier, Y., Jean-Baptiste, P., Fourré, E., Chazallon, B., and The Zairov Leg 2 Scientific Party: Physi- cal and chemical characterization of gas hydrates and associated methane plumes in the Congo-Angola Basin, Chem. Geol., 205, 405-425, doi:10.1016/j.chemgeo.2003.12.033, 2004.

Childress, J. J. and Fisher, C. R.: The biology of hydrothermal vent animals: physiology, biochemistry, and autotrophic symbioses, Oceanogr. Mar. Biol., 30, 337-441, 1992.

Clarke, K. R.: Non-parametric multivariate analysis of changes in community structure, Aust. J. Ecol., 18, 117-143, doi:10.1111/j.1442-9993.1993.tb00438.x, 1993.

Cline, J. D.: Spectrophotometric determination of hydrogen sulfide in natural waters, Limnol. Oceanogr., 14, 454-458, 1969.

Cordes, E. E., Arthur, M. A., Shea, K., Arvidson, R. S., and Fisher, C. R.: Modeling the mutualistic interactions between tubeworms and microbial consortia., PLoS Biology, 3, e77, doi:10.1371/journal.pbio.0030077, 2005.

Cordes, E. E., Cunha, M. R., Galéron, J., Mora, C., Olu-Le Roy, K., Sibuet, M., Van Gaever, S., Vanreusel, A., and Levin, L. A.: The influence of geological, geochemical, and biogenic habitat heterogeneity on seep biodiversity, Mar. Ecol., 31, 51-65, doi:10.1111/j.1439-0485.2009.00334.x, 2010.

Dando, P. R. and Hovland, M.: Environmental effects of submarine seeping natural gas, Cont. Shelf Res., 12, 1197-1207, doi:10.1016/0278-4343(92)90079-Y, 1992.

de Beer, D., Sauter, E., Niemann, H., Kaul, N., Foucher, J.-P., Witte, U., Schlüter, M., and Boetius, A.: In situ fluxes and zonation of microbial activity in surface sediments of the Håkon Mosby Mud Volcano, Limnol. Oceanogr., 51, 1315-1331, 2006.

Decker, C., Morineaux, M., Van Gaever, S., Caprais, J.-C., Lichtschlag, A., Gauthier, O., Andersen, A. C., and Olu, K.: Habitat heterogeneity influences cold-seep macrofaunal communities within and among seeps along the Norwegian margin. Part 1: macrofaunal community structure, Mar. Ecol., 33, 205-230, doi:10.1111/j.1439-0485.2011.00503.x, 2011.

Decker, C., Caprais, J.-C., Khripounoff, A., and Olu, K.: First respiration estimates of cold-seep vesicomyid bivalves from in situ total oxygen uptake measurements, C. R. Biol., 335, 261-270, doi:10.1016/j.crvi.2012.03.002, 2012.

Duperron, S., Nadalig, T., Caprais, J.-C., Sibuet, M., Fiala-Medioni, A., Amann, R., and Dubilier, N.: Dual Symbiosis in a Bathymodiolus sp. mussel from a Methane Seep on the Gabon Continental Margin (Southeast Atlantic): 16S rRNA Phylogeny and Distribution of the Symbionts in Gills, Appl. Environ. Microb., 71, 1694-1700, doi:10.1128/AEM.71.4.1694-1700.2005, 2005.

Duperron, S., Lorion, J., Samadi, S., Gros, O., and Gaill, F.: Symbioses between deep-sea mussels (Mytilidae: Bathymodiolinae) and chemosynthetic bacteria: diversity, function and evolution., C. R. Biol., 332, 298-310, doi:10.1016/j.crvi.2008.08.003, 2009.

Duperron, S., Guezi, H., Gaudron, S. M., Pop Ristova, P., Wenzhöfer, F., and Boetius, A.: Relative abundances of methaneand sulphur-oxidising symbionts in the gills of a cold seep mussel and link to their potential energy sources, Geobiology, 9, 481491, doi:10.1111/j.1472-4669.2011.00300.x, 2011.

Felden, J., Wenzhöfer, F., Feseker, T., and Boetius, A.: Transport and consumption of oxygen and methane in different habitats of the Håkon Mosby Mud Volcano (HMMV), 2010.

Fischer, D., Sahling, H., Nöthen, K., Bohrmann, G., Zabel, M., and Kasten, S.: Interaction between hydrocarbon seepage, chemosynthetic communities, and bottom water redox at cold seeps of the Makran accretionary prism: insights from 
habitat-specific pore water sampling and modeling, Biogeosciences, 9, 2013-2031, doi:10.5194/bg-9-2013-2012, 2012.

Fisher, M. M. and Triplett, E. W.: Automated approach for ribosomal intergenic spacer analysis of microbial diversity and its application to freshwater bacterial communities, Appl. Environ. Microbiol, 65, 4630-4636, 1999.

Garbe-Schönberg, D., Koschinsky, A., Ratmeyer, V., Jähmlich, H., and Westernstroeer, U.: KIPS - A new Multiport Valve-based all-Teflon Fluid Sampling System for ROVs, in: Geophysical Research Abstracts, vol. 8, p. 07032, 2006.

Gay, A., Lopez, M., Cochonat, P., Sultan, N., Cuquil, E., and Brigaud, F.: Sinuous pockmark belt as indicator of a shallow buried turbiditic channel on the lower slope of the Congo basin, West African margin, Geol. Soc. Lond. Spec. Publ., 216, 173$189,2003$.

Girnth, A.-C., Grünke, S., Lichtschlag, A., Felden, J., Knittel, K., Wenzhöfer, F., de Beer, D., and Boetius, A.: A novel, matforming Thiomargarita population associated with a sulfidic fluid flow from a deep-sea mud volcano, Environ. Microbiol., 13, 495505, doi:10.1111/j.1462-2920.2010.02353.x, 2010.

Grasshoff, K., Kremling, K., and Ehrhardt, M.: Methods of Seawater Analysis, 3rd editio., WILEY-VCH Verlag GmbH, Weinheim, Germany, 1999.

Grünke, S., Felden, J., Lichtschlag, A., Girnth, A.-C., De Beer, D., Wenzhöfer, F., and Boetius, A.: Niche differentiation among matforming, sulfide-oxidizing bacteria at cold seeps of the Nile Deep Sea Fan (Eastern Mediterranean Sea), Geobiology, 9, 330-348, doi:10.1111/j.1472-4669.2011.00281.x, 2011.

Hall, P. O. J. and Aller, R. C.: Rapid, small-volume, flow injection analysis for $\Sigma \mathrm{CO}_{2}$ and $\mathrm{NH}_{4}^{+}$in marine and freshwaters analysis f, Limnol. Oceanogr., 37, 1113-1119, 1992.

Heijs, S. K., Haese, R. R., van der Wielen, P. W. J. J., Forney, L. J., and van Elsas, J. D.: Use of $16 \mathrm{~S}$ rRNA gene based clone libraries to assess microbial communities potentially involved in anaerobic methane oxidation in a Mediterranean cold seep, Microb. Ecol., 53, 384-398, doi:10.1007/s00248-006-9172-3, 2007.

Hewson, I. and Fuhrman, J. A.: Improved strategy for comparing microbial assemblage fingerprints, Microb. Ecol., 51, 147-153, doi:10.1007/s00248-005-0144-9, 2006.

Joye, S. B., Bowles, M. W., Samarkin, V. A., Hunter, K. S., and Niemann, H.: Biogeochemical signatures and microbial activity of different cold-seep habitats along the Gulf of Mexico deep slope, Deep-Sea Res. Pt. II, 57, 1990-2001, doi:10.1016/j.dsr2.2010.06.001, 2010.

Jørgensen, B. B.: A comparison of methods for the quantification of bacterial sulphate reduction in coastal marine sediments: I. Measurements with radiotracer techniques, Geomicrobiol. J., 1, 11-27, 1978.

Jørgensen, B. B. and Boetius, A.: Feast and famine - microbial life in the deep-sea bed, Nature, 5, 770-781, doi:10.1038/nrmicro1745, 2007.

Jørgensen, B. B. and Des Marais, D. J.: The diffusive boundary layer of sediments: oxygen microgradients over a microbial mat, Limnol. Oceanogr., 35, 1343-1355, 1990.

Kallmeyer, J., Ferdelman, T. G., Weber, A., Fossing, H., and Jørgensen, B. B.: A cold chromium distillation procedure for radiolabeled sulfide applied to sulfate reduction measurements, Limnol. Oceanogr.-Methods, 2, 171-180, 2004.
Kennicutt II, M. C., Brooks, J. M., Bidigare, R. R., Fay, R. R., Wade, T. L. and McDonald, T. J.: Vent-type taxa in a hydrocarbon seep region on the Louisiana sloe, Nature, 317, 351-353, 1985.

Knittel, K. and Boetius, A.: Anaerobic Methane Oxidizers, in Handbook of Hydrocarbon and Lipid Microbiology, edited by: Timmis, K. N., p. 4699, Springer Berlin Heidelberg, Berlin, Heidelberg, 2010.

Knittel, K., Boetius, A., Lemke, A., Eilers, H., Lochte, K., Pfannkuche, O., and Linke, P.: Activity, distribution, and diversity of Sulfate Reducers and Other Bacteria in Sediments above Gas Hydrate (Cascadia Margin, Oregon), Geomicrobiol. J., 20, 269-294, doi:10.1080/01490450303896, 2003.

Krylova, E. M. and Sahling, H.: Vesicomyidae (Bivalvia ): Current Taxonomy and Distribution, Scan. Electron Micros., 5, e9957, doi:10.1371/journal.pone.0009957, 2010.

Küster-Heins, K., de Lange, G. J., and Zabel, M.: Benthic phosphorus and iron budgets for three NW African slope sediments: a balance approach, Biogeosciences, 7, 469-480, doi:10.5194/bg7-469-2010, 2010.

Legendre, P. and Gallagher, E.: Ecologically meaningful transformations for ordination of species data, Oecologia, 129, 271-280, doi:10.1007/s004420100716, 2001.

Legendre, P. and Legendre, L.: Numerical Ecology, second, Elsevier Science, 1998.

Lessard-Pilon, S., Porter, M. D., Cordes, E. E., MacDonald, I., and Fisher, C. R.: Community composition and temporal change at deep Gulf of Mexico cold seeps, Deep-Sea Res. Pt. II, 57, 18911903, doi:10.1016/j.dsr2.2010.05.012, 2010.

Levin, L. A.: Ecology of cold seep sediment: interactions of fauna with flow, chemistry and microbes, Oceanogr. Mar. Biol., 43, 146, 2005.

Levin, L. A., Mendoza, G. F., Gonzalez, J. P., Thurber, A. R., and Cordes, E. E.: Diversity of bathyal macrofauna on the northeastern Pacific margin: the influence of methane seeps and oxygen minimum zones, Mar. Ecol., 31, 94-110, doi:10.1111/j.14390485.2009.00335.x, 2010.

Levin, L. L., Ziebis, W., Mendoza, G. F., Growney, V. A., Tryon, M. D., Brown, K. B., Mahn, C., Gieskes, J. M., and Rathburn, A. E.: Spatial heterogeneity of macrofauna at northern California methane seeps: influence of sulfide concentration and fluid flow, Mar. Ecol.-Prog. Ser., 265, 123-139, doi:10.3354/meps265123, 2003.

Li, Y.-H. and Gregory, S.: Diffusion of ions in sea water and in deepsea sediments, Geochim. Cosmochim. Ac., 38, 703-714, 1974.

Lichtschlag, A., Felden, J., Bruechert, V., Boetius, A., and de Beer, D.: Geochemical processes and chemosynthetic primary production in different thiotrophic mats of the Håkon Mosby Mud Volcano (Barents Sea), Limnol. Oceanogr., 55, 931-949, 2010a.

Lichtschlag, A., Felden, J., Wenzhöfer, F., Schubotz, F., Ertefai, T. F., Boetius, A., and de Beer, D.: Methane and sulfide fluxes in permanent anoxia: In situ studies at the Dvurechenskii mud volcano (Sorokin Trough, Black Sea), Geochim. Cosmochim. Ac., 74, 5002-5018, doi:10.1016/j.gca.2010.05.031, 2010 b.

Luff, R. and Wallmann, K.: Fluid flow, methane fluxes, carbonate precipitation and biogeochemical turnover in gas hydrate-bearing sediments at Hydrate Ridge, Cascadia Margin: numerical modeling and mass balances, Geochim. Cosmochim. Ac., 67, 34033421, doi:10.1016/S0016-7037(03)00127-3, 2003. 
Lösekann, T., Knittel, K., Nadalig, T., Fuchs, B., Niemann, H., Boetius, A., and Amann, R.: Diversity and abundance of aerobic and anaerobic methane oxidizers at the Håkon Mosby Mud Volcano, Barents Sea, Appl. Environ. Microb., 73, 3348-3362, doi:10.1128/AEM.00016-07, 2007.

Menot, L., Galeron, J., Olu, K., Caprais, J.-C., Crassous, P., Khripounoff, A., and Sibuet, M.: Spatial heterogeneity of macrofaunal communities in and near a giant pockmark area in the deep Gulf of Guinea, Mar. Ecol., 31, 78-93, doi:10.1111/j.14390485.2009.00340.x, 2010.

Meyer-Reil, L. A.: Benthic response to sedimentation events during autumn to spring at a shallow-water station in the Western Kiel Bight, Mar. Biol., 77, 247-256, 1983.

Niemann, H., Lösekann, T., de Beer, D., Elvert, M., Nadalig, T., Knittel, K., Amann, R., Sauter, E. J., Schlüter, M., Klages, M., Foucher, J. P., and Boetius A.: Novel microbial communities of the Håkon Mosby mud volcano and their role as a methane sink, Nature, 443, 854-858, doi:10.1038/nature05227, 2006.

Niemann, H., Fischer, D., Graffe, D., Knittel, K., Montiel, A., Heilmayer, O., Nöthen, K., Pape, T., Kasten, S., Bohrmann, G., Boetius, A., and Gutt, J.: Biogeochemistry of a low-activity cold seep in the Larsen B area, western Weddell Sea, Antarctica, Biogeosciences, 6, 2383-2395, doi:10.5194/bg-6-2383-2009, 2009.

Oksanen, J., Blanchet, F. G., Roeland, K., Legendre, P., Minchin, P. R., O’Hara, R. B., Simpson, G. L., Solymos, P., Stevens, M. H. H., and Wagner, H.: vegan: Community Ecology Package, R package version 2.0-2., 2011.

Olu, K., Caprais, J. C., Galéron, J., Causse, R., von Cosel, R., Budzinski, H., Le Ménach, K., Le Roux, C., Levaché, D., Khripounoff, A., and Sibuet, M.: Influence of seep emission on the non-symbiont-bearing fauna and vagrant species at an active giant pockmark in the Gulf of Guinea (Congo-Angola margin), Deep-Sea Res. Pt. II, 56, 2380-2393, doi:10.1016/j.dsr2.2009.04.017, 2009.

Olu, K., Cordes, E. E., Fisher, C. R., Brooks, J. M., Sibuet, M., and Desbruyères, D.: Biogeography and Potential Exchanges Among the Atlantic Equatorial Belt Cold-Seep Faunas, PloS one, 5, 111, doi:10.1371/journal.pone.0011967, 2010.

Olu-Le Roy, K., Caprais, J.-C., Fifis, A., Fabri, M.-C., Galéron, J., Budzinsky, H., Le Ménach, K., Khripounoff, A., Ondréas, H., and Sibuet, M.: Cold-seep assemblages on a giant pockmark off West Africa: spatial patterns and environmental control, Mar. Ecol., 28, 115-130, doi:10.1111/j.1439-0485.2006.00145.x, $2007 a$.

Olu-Le Roy, K., Cosel, R. V., Hourdez, S., Carney, S. L., and Jollivet, D.: Amphi-Atlantic cold-seep Bathymodiolus species complexes across the equatorial belt, Deep Sea Res. Pt. I, 54, 18901911, doi:10.1016/j.dsr.2007.07.004, 2007b.

Ondréas, H., Olu, K., Fouquet, Y., Charlou, J. L., Gay, A., Dennielou, B., Donval, J. P., Fifis, A., Nadalig, T., Cochonat, P., Cauquil, E., Bourillet, J. F., Le Moigne, M., and Sibuet, M.: ROV study of a giant pockmark on the Gabon continental margin, GeoMar. Lett, 25, 281-292, doi:10.1007/s00367-005-0213-6, 2005.

Orcutt, B. N., Joye, S. B., Kleindienst, S., Knittel, K., Ramette, A., Reitz, A., Samarkin, V., Treude, T., and Boetius, A.: Impact of natural oil and higher hydrocarbons on microbial diversity, distribution, and activity in Gulf of Mexico cold-seep sediments, Deep-Sea Res. Pt. II, 57, 2008-2021, doi:10.1016/j.dsr2.2010.05.014, 2010.
Paull, C. K., Hecker, B., Commeau, R., Freeman-Lynde, R. P., Neumann, C., Corso, W. P., Golubic, S., Hook, J. E., Sikes, E., and Curray, J.: Biological communities at the Florida escarpment resemble hydrothermal vent taxa, Science, 226, 965-967, 1984.

Petersen, J. M. and Dubilier, N.: Methanotrophic symbioses in marine invertebrates, Environ. Microbiol. Reports, 1, 319-335, doi:10.1111/j.1758-2229.2009.00081.x, 2009.

Pierre, C. and Fouquet, Y.: Authigenic carbonates from methane seeps of the Congo deep-sea fan, Geo-Mar. Lett., 27, 249-257, doi:10.1007/s00367-007-0081-3, 2007.

Ramette, A.: Multivariate analyses in microbial ecology, FEMS Microbiol. Ecol., 62, 142-160, doi:10.1111/j.15746941.2007.00375.x, 2007.

Ramette, A.: Quantitative community fingerprinting methods for estimating the abundance of operational taxonomic units in natural microbial communities, Appl. Environ. Microb., 75, 2495-2505, doi:10.1128/AEM.02409-08, 2009.

Ramette, A. and Tiedje, J. M.: Multiscale responses of microbial life to spatial distance and environmental heterogeneity in a patchy ecosystem., P. Natl. Acad. Sci. USA, 104, 2761-2766, doi:10.1073/pnas.0610671104, 2007.

Revsbech, N. P.: An oxygen microsensor with a guard cathode, Limnol. Oceanogr., 34, 474-478, 1989.

Ritt, B., Pierre, C., Gauthier, O., Wenzhöfer, F., Boetius, A., and Sarrazin, J.: Diversity and distribution of cold-seep fauna associated with different geological and environmental settings at mud volcanoes and pockmarks of the Nile Deep-Sea Fan, Mar. Biol., 158, 1187-1210, doi:10.1007/s00227-011-1679-6, 2011.

Sahling, H., Rickert, D., Lee, R. W., Linke, P., and Suess, E.: Macrofaunal community structure and sulfide flux at gas hydrate deposits from the Cascadia convergent margin, NE Pacific, Mar. Ecol.-Prog. Ser., 231, 121-138, doi:10.3354/meps231121, 2002.

Sahling, H., Bohrmann, G., Spiess, V., Bialas, J., Breitzke, M., Ivanov, M., Kasten, S., Krastel, S., and Schneider, R.: Pockmarks in the Northern Congo Fan area, SW Africa: Complex seafloor features shaped by fluid flow, Mar. Geol., 249, 206-225, doi:10.1016/j.margeo.2007.11.010, 2008.

Seeberg-Elverfeldt, J., Schlüter, M., Feseker, T., and Koelling, M.: Rhizon sampling of porewaters near the sediment-water interface of aquatic systems, Limnol. Oceanogr.-Methods, 3, 361$371,2005$.

Shepard, R. N.: Metric structures in ordinal data, J. Math. Psychol., 3, 287-315, doi:10.1016/0022-2496(66)90017-4, 1966.

Sibuet, M. and Olu, K.: Biogeography, biodiversity and fluid dependence of deep-sea cold-seep communities at active and passive margins, Deep-Sea Res. Pt. II, 45, 517-567, doi:10.1016/S09670645(97)00074-X, 1998.

Sibuet, M. and Olu-Le Roy, K.: Cold Seep Communities on Continental Margins: Structure and Quantitative Distribution Relative to Geological and Fluid Venting Patterns, in Ocean Margin Systems, edited by: Wefer, G., Billett, D., Hebbeln, D., Jorgensen, B. B., Schlueter, M., and van Weering, T. C. E., p. 501, SpringerVerlag Berlin Heidelberg New York, Heidelberg, 2002.

Sibuet, M. and Vangriesheim, A.: Deep-sea environment and biodiversity of the West African Equatorial margin, Atlantic, 56, 2156-2168, doi:10.1016/j.dsr2.2009.04.015, 2009.

Sievert, S. M., Kiene, P., and Schulz-Vogt, H. N.: The Sulfur Cycle, Oceanography, 20, 117-123, 2007. 
Sommer, S., Pfannkuche, O., Linke, P., Luff, R., Greinert, J., Drews, M., Gubsch, S., Pieper, M., Poser, M., and Viergutz, T.: Efficiency of the benthic filter: Biological control of the emission of dissolved methane from sediments containing shallow gas hydrates at Hydrate Ridge, Global Biogeochem. Cy., 20, GB2019, doi:10.1029/2004GB002389, 2006.

Sommer, S., Linke, P., Pfannkuche, O., Niemann, H., and Treude, T.: Benthic respiration in a seep habitat dominated by dense beds of ampharetid polychaetes at the Hikurangi Margin (New Zealand ), Mar. Geol., 272, 223-232, doi:10.1016/j.margeo.2009.06.003, 2010.

Suess, E., Carson, B., Ritger, S. D., Moore, J. C., Jones, M. L., Kulm, L. D., and Cochrane, G. R.: Biological communities at vent sites along the subduction zone off Oregon, in Hydrothermal vents of the Eastern Pacific: An overview, edited by: Jones, M., p. 547, INFAX, Vienna, Va., 1985.

Suess, E., Torres, M. E., Bohrmann, G., Collier, R. W., Greinert, J., Linke, P., Rehder, G., Trehu, A., Wallmann, K., Winckler, G., and Zuleger, E.: Gas hydrate destabilization: enhanced dewatering, benthic material turnover and large methane plumes at the Cascadia convergent margin, Earth Planet. Sci. Lett., 170, 1-15, doi:10.1016/S0012-821X(99)00092-8, 1999.

Thiele, J. and Jaeckel, S.: Muscheln der Deutschen TiefseeExpedition., Wissenschaftliche Ergebnisse der Deutschen Tiefsee-Expedition auf dem Dampfer "Valdivia", 21, 159-268, 1931.

Torres, M. E., McManus, J., Hammond, D. E., de Angelis, M. A., Heeschen, K. U., Colbert, S. L., Tryon, M. D., Brown, K. M., and Suess, E.: Fluid and chemical fluxes in and out of sediments hosting methane hydrate deposits on Hydrate Ridge, OR, I: Hydrological provinces, Earth Planet. Sci. Lett., 201, 3-4, 525-540, doi:10.1016/S0012-821X(02)00733-1, 2002.

Treude, T., Boetius, A., Knittel, K., Wallmann, K., and Jørgensen, B. B.: Anaerobic oxidation of methane above gas hydrates at Hydrate Ridge, NE Pacific Ocean, Mar. Ecol.-Prog. Ser., 264, 1-14, 2003.

Tunnicliffe, V.: The biology of hydrothermal vents: ecology and evolution, Oceanogr. Mar. Biol., 29, 319-407, 1991.
Tunnicliffe, V., McArthur, A. G., and McHugh, D.: A biogeographical perspective of the deep-sea hydrothermal vent fauna, edited by: Blaxter, J. H. S., Southward, A. J., and Tyler, P. A., Adv. Mar. Biol., 34, 353-442, 1998.

Tyler, P. A., German, C. R., Ramirez-Llodra, E., and Van Dover, C. L.: Understanding the biogeography of chemosynthetic ecosystems Comprendre la biogéographie des écosystèmes chémosynthétiques, Oceanol. Acta, 25, 227-241, 2003.

Valentine, D. L.: Biogeochemistry and microbial ecology of methane oxidation in anoxic environments: a review, Anton. Leeuw., 81, 271-282, 2002.

Van Gaever, S., Galéron, J., Sibuet, M., and Vanreusel, A.: Deepsea habitat heterogeneity influence on meiofaunal communities in the Gulf of Guinea, Deep-Sea Res. Pt. II, 56, 2259-2269, doi:10.1016/j.dsr2.2009.04.008, 2009.

Vanreusel, A., Andersen, A. C., Boetius, A., Connely, D., Cunha, M. R., Decker, C., Hilario, A., Kormas, K. A., Maignien, L., Olu, K., Pachiadaki, M., Ritt, B., Rodrigues, C., Sarrazin, J., Tyler, P., Van Gaever, S., and Vanneste, H.: Biodiversity of Cold Seep Ecosystems along the European Margins, Oceanography, 22, 110-127, 2009.

von Cosel, R. and Olu, K.: Large Vesicomyidae (Mollusca: Bivalvia) from cold seeps in the Gulf of Guinea off the coasts of Gabon, Congo and northern Angola, Deep Sea Res. Pt. II, 56, 2350-2379, doi:10.1016/j.dsr2.2009.04.016, 2009.

Wenzhöfer, F. and Glud, R. N.: Benthic carbon mineralization in the Atlantic: a synthesis based on in situ data from the last decade, Deep-Sea Res. Pt. I, 49, 1255-1279, doi:10.1016/S09670637(02)00025-0, 2002.

Wenzhöfer, F., Holby, O., Glud, R. N., Nielsen, H. K., and Gundersen, J. K.: In situ microsensor studies of a shallow water hydrothermal vent at Milos, Greece, Mar. Chem., 69, 43-54, 2000.

Whittaker, R. H.: Vegetation of the Siskiyou Mountains, Oregon and California, Ecol. Monogr., 30, 279-338, 1960.

Zabel, M. and Schulz, H. D.: Importance of submarine landslides for non-steady state conditions in pore water systemslower Zaire (Congo) deep-sea fan, Mar. Geol., 176, 87-99, 2001. 